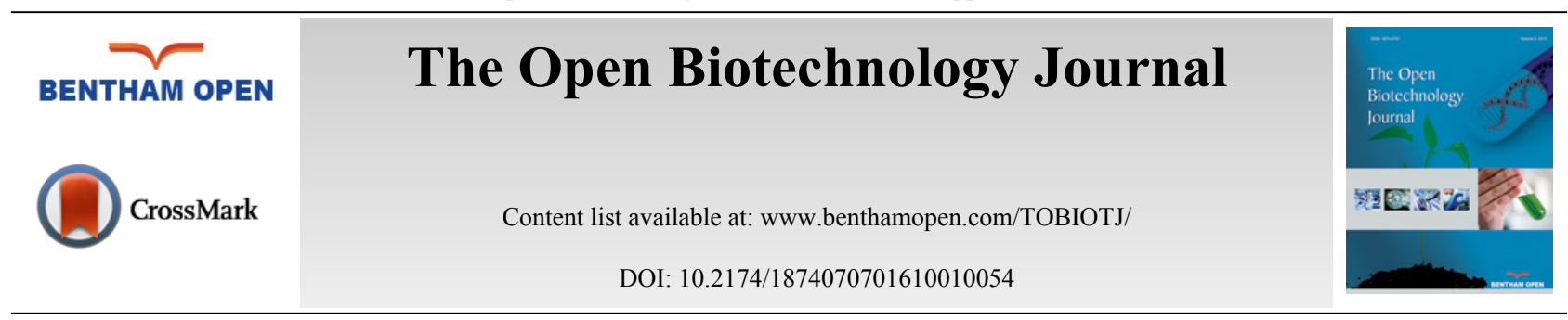

\title{
Effects of Endocrine-disrupting Chemicals on Female Reproductive Health
}

\author{
Aparna Mahakali Zama*, Arpita Bhurke and Mehmet Uzumcu \\ Department of Animal Sciences, Rutgers, The State University of New Jersey, 84 Lipman Drive, New Brunswick, NJ \\ 08901, USA
}

\begin{abstract}
Endocrine-disrupting chemicals (EDCs) are increasingly prevalent in the environment and the evidence demonstrates that they affect reproductive health, has been accumulating for the last few decades. In this review of recent literature, we present evidence of the effects of estrogen-mimicking EDCs on female reproductive health especially the ovaries and uteri. As representative EDCs, data from studies with a pharmaceutical estrogen, diethylstilbestrol (DES), an organochlorine pesticide methoxychlor (MXC), a phytoestrogen (genistein), and a chemical used in plastics, bisphenol a (BPA) have been presented. We also discuss the effects of a commonly found plasticizer in the environment, a phthalate (DEHP), even though it is not a typical estrogenic EDC. Collectively, these studies show that exposures during fetal and neonatal periods cause developmental reprogramming leading to adult reproductive disease. Puberty, estrous cyclicity, ovarian follicular development, and uterine functions are all affected by exposure to these EDCs. Evidence that epigenetic modifications are involved in the progression to adult disease is also presented.
\end{abstract}

Keywords: Bisphenol A, diethylstilbestrol, developmental reprogramming, endocrine-disrupting chemicals (EDCs), epigenetic, female reproductive health, genistein, methoxychlor, phthalate, ovary, uterus, xenoestrogen.

\section{INTRODUCTION}

It is well known that toxic contaminants in air, water, and agricultural produce have contributed to exposure to mutagens that cause numerous health problems including cancers [1 - 3]. Large numbers of these xenobiotics are endocrine-disrupting chemicals (EDCs) that are, in general, not mutagenic but can cause more subtle effects: they cause disruption in hormone synthesis and signaling. While many hormone responsive organs are sensitive to EDCs, the ovaries and uteri are most sensitive to the EDCs that mimic estrogen, the female steroid hormone.

The direct consequences of the detrimental effects of EDCs on female reproductive health are impaired reproductive organ function, infertility and/or cancer. However ovarian dysfunction can lead to reduced serum estradiol levels, which are associated with increased risk of cardiovascular diseases [4], loss of bone density [5, 6], and sexual dysfunction [7]. In addition, the effects on the female germ cells, the oocytes, can potentially cause multigenerational effects. Therefore, EDCs that disrupt female reproductive health have long-term and widespread effects. Furthermore, the ubiquitous expression of estrogen receptors (ERs) in multiple tissues make the actions of myriad xenoestrogens possible.

It has been shown in numerous epidemiological studies that women's reproductive health is severely affected by exposure to estrogenic EDCs in the form of pharmaceuticals, pesticides, industrial products such as plasticizers, and phytoestrogens [8 - 13]. The impaired fecundity rate in the U.S. increased from $11 \%$ to $15 \%$ between 1982 and 2002 $[14,15]$. Although various confounding factors such as lifestyle changes could have contributed to this decline, the role of EDCs cannot be discounted. The incidence of female reproductive disorders such as early puberty, premature ovarian failure, impaired fertility as well as breast, ovarian, and uterine cancers [16] have been documented in animal studies

\footnotetext{
* Address correspondence to this author at the Department of Animal Sciences, School of Environmental and Biological Sciences, Rutgers, The State University of New Jersey, 84 Lipman Drive, New Brunswick, NJ 08901-8525, USA; Tel: +1-848-932-8495; Fax: +1-732-932-6996; E-mail: zama@aesop.rutgers.edu
} 
with estrogenic EDCs and have been substantiated by a large body of epidemiological evidence from humans and wildlife as well [17 - 23].

Exposures to EDCs in adulthood cause severe reproductive disorders as mentioned above but the most long-lasting diseases that occur by adulthood are caused by exposures in fetal and neonatal periods [24, 25]. Embryonic epigenetic programming is fine-tuned during differentiation and development of the organs [26]. Developmental reprogramming of the organs involves disruption in the epigenetic reprogramming and has been considered to be a mechanism by which the developmental trajectory of these organs is altered [26 - 28]. The somatic components of the ovary develop during mid-to-late gestation and are modified throughout postnatal folliculogenesis [29]. Similarly, it is proposed that epigenetic reprogramming of the uterine epithelium occurs as the early developmental, tissue organizational events take place in the first week after birth in rodents [30]. Therefore any disruption in the ovarian and uterine epigenomes at this stage could lead to altered gene expression by adulthood [24, 31 - 33]. In addition, germ cells undergo their own epigenetic programming: the germ cell epigenome that is methylated early in embryonic stage is demethylated in midgestation, and remethylated in a sex-specific manner at tissue-specific developmental stages [27, 28], Specifically, female germ cell remethylation is initiated during the early postnatal period, during follicular assembly and initial recruitment, and continues throughout oocyte growth until the antral follicle stage specifically in rodents [34]. Recent observations in mouse and bird embryos have shown that the precursors of oocytes (primordial germ cells) express functional estrogen receptors, namely ESR-1 and GPR-30, respectively, which may be able to activate non-genomic signaling in such cells via the PI3K/AKT signaling pathway $[35,36]$. These germ cell processes can also be a target for EDCs, suggesting that EDCs might affect germ cell development during a crucial period of their nuclear reprogramming [37].

There are numerous lines of evidence emerging that suggest that the exposure to estradiol or estrogenic EDCs can cause epigenetic alterations in sensitive developmental windows that might have long-term effects by adulthood $[25,38]$. DNA ( $\mathrm{CpG})$ methylation and histone modifications are necessary for tissue-specific gene regulation. Usually, an increase in DNA methylation at a locus is associated with the interference of transcription factor (TF) binding, resulting in down-regulation of gene expression, and vice versa [39 - 42]. Post-translational modifications on histone proteins of the nucleosomes such as acetylation, methylation, and phosphorylation at specific amino acid residues (lysine, arginine, serine, or threonine) contribute either to euchromatin or the silencing of loci (heterochromatin). This silencing can be reversible or irreversible, depending on further modification [43 - 46]. For example, some histone methylation events (e.g., H3K9me3) work in conjunction with DNA methylation to stably silence genes [47].

\section{CRITICAL OVARIAN AND UTERINE DEVELOPMENTAL STAGES SENSITIVE TO ESTROGENIC EDCS}

A female's reproductive lifespan depends on the size and health of the initial pool of primordial follicles and their progression and maturation into primary, secondary, antral, and eventually ovulatory follicles. Complex bidirectional communication occurs between the oocyte and its surrounding somatic cells involving stimulatory inputs from local paracrine factors as well as steroid hormones [48 - 50]. The gonadotropins, follicle stimulating hormone (FSH) and luteinizing hormone (LH), have a significant role in the selection and maturation of the follicles via stimulation of IGF-1 and estrogen signaling pathways among others [51]. Once an oocyte is fertilized, the implantation of the embryo into the uterus and successful pregnancy and parturition are dependent on healthy uterine function. Critical uterine developmental windows overlap with those of the ovary in the first two weeks after birth, with the development of luminal epithelium and the stromal glandular epithelium. These processes are regulated by the WNT and HOX gene families and are responsive to IGF-1 and estrogen signaling as well [52 - 54]. Therefore, estrogenic EDC exposures during early ovarian and uterine development are a major threat and have the potential to reprogram ovarian and uterine functions.

\subsection{Primordial Follicle Development and Transition to Primary Follicles in Ovaries}

Oocytes are arrested at the early diplotene phase of meiotic prophase I and enclosed in nests surrounded by somatic pregranulosa cells. Starting at E16.5, in mice and rats, most oocytes are eliminated via apoptosis [55 - 57]. The remaining oocytes are surrounded by a single layer of flattened pregranulosa cells and form the primordial follicles, a process that is almost complete by PND 3-4. Most of the primordial follicles remain quiescent, but some begin growing and transition to the next stage, primary follicles. Both of these early processes, primordial follicle formation and primordial to primary follicle transition (the initial recruitment), are tightly regulated by interactions between paracrine 
factors, transcription factors, and steroid hormones while being independent of gonadotropins. However, since these processes determine the success of female reproduction, endocrine disruption can lead to early depletion of follicles and therefore may result in early reproductive senescence [50].

In mouse and rat models, estradiol and progesterone have been shown to inhibit primordial follicle formation by inhibiting apoptosis $[48,49]$ a process that could be reversed by pro-apototic TNF $\alpha$ [58, 59]. The actions of estradiol and estrogenic EDCs (e.g., DES) may involve the inhibition of pro-apoptotic molecules, such as Fas ligand [60] leading to multioocyte follicles (MOFs) that in the long-term, do not progress to healthy ovulations [48]. On the other hand, activins have a stimulatory role in primordial follicle formation. Neonatal activin treatment increased the number of postnatal primordial follicle by $30 \%$ in mice. However, the excessive number of follicles was not maintained at puberty or beyond [61]. Thus, there is an interplay between the inhibitory activity of estradiol and the stimulatory role of activins in follicular formation. Neonatal estradiol or DES exposures induce MOFs but also inhibit activin levels in the ovary [62]. These results suggest that the paracrine systems that control the primordial follicle formation process can be influenced by estrogenic EDCs.

The oocyte-derived FOXO3 is a major suppressor of primordial to primary follicle transition [63]. When it is deleted in mice, although the initial primordial follicle pool is established normally, primordial follicles are activated en masse, leading to early elimination of follicular reserve and reproductive senescence. Androgens inhibit FOXO3 activity [64], and also suppress the expression of growth differentiation factor-9 (GDF9), a well-known stimulator of follicle development beyond the primary stage. As a result, exposure to androgens causes an accumulation of preantralstage follicles. Overall, estrogens may inhibit the initial recruitment by stimulating inhibitory paracrine factors (e.g., $\mathrm{AMH}$ ) while androgens may stimulate the initial recruitment by inhibiting suppressive factors (e.g., FOXO3).

\subsection{Follicle Selection, Antral Follicle Development, and Ovulation}

A single follicle or multiple follicles, in monoovulators versus polyovulators, within a recruited cohort is/are selected at the antral stage to complete folliculogenesis and achieve ovulation. An important criterion (among several) for the selection is that the follicle secretes high levels of estradiol. Local growth factors such as insulin-like growth factors (IGFs), activins, transforming growth factor (TGF) $\alpha$ and $\beta$, hepatocyte growth factor, and FGF7 are also required for this process [65].

In addition, IGFs are considered to be critical for follicular maturation since they stimulate cell proliferation and steroidogenesis in granulosa cells of various species [66, 67]. In contrast, IGF binding proteins (IGFBPs) can suppress FSH-induced follicular growth and differentiation by sequestering IGF-I protein and inhibiting its activity that leads to atresia $[68,69]$. Prior to maturation, estradiol production is markedly elevated in the selected antral follicles, which exerts a positive-feedback effect on gonadotropin secretion. The rise in FSH and LH supports further increase in steroidogenesis and initiates luteinization, whereby granulosa cells switch from an almost exclusive production of estradiol to the production of both estradiol and progesterone. The feedback dynamics within the HPG axis continue and culminate with the preovulatory LH that stimulates ovulation [70]. Multiple factors play roles in ovulation, including ESR2, progesterone receptor, proteases, epidermal growth factor-like proteins, and prostaglandin synthase-2 (see [70] for review). Following ovulation, the remnants of the ovulated follicle are stimulated by LH to terminally differentiate into the corpus luteum (CL). The CL, as a primary source of progesterone, is essential for enabling the initiation and maintenance of pregnancy (reviewed in [71, 72]).

A salient point to be noted regarding these processes is that the ovary is a hormone-responsive tissue and contains follicles at every stage of development that are highly dynamic and require temporal and cell-specific and stage dependent regulation of numerous genes, which could be controlled by epigenetic mechanisms. Therefore they can be affected by developmental exposures to EDCs thus making the ovary a unique target for EDCs for epigenetic modulation.

\subsection{Critical Steps in Prenatal and Postnatal Uterine Organogenesis}

The female reproductive tract (FRT) - oviducts, uteri, cervix, and vagina - develops from the Mullerian ducts (MD) in females [73]. The development of the FRT has been described in detail previously [74]. For the purpose of understanding the most severe effects of EDCs on the FRT, uterine development is most pertinent to this review. The uterus has varied roles depending on the reproductive stage: implantation, maintenance of pregnancy, and parturition. Prenatal uterine organogenesis involves the regression of the Wolffian ducts in the absence of MIS and testosterone and the development of the MD after the sexual differentiation of the XX gonad. Fusion of the MDs and formation of the 
uterus is complete by E16. Mice and rats have a duplex uterus while humans have a single uterus, however the histological architecture has similarities. The uterus consists of the endometrium, whose structure actively alters during the estrous/menstrual cycle, and the myometrium that has a smooth muscle layer that sorrounds the endometrium. The luminal epithelium (LE) of the endometrium is composed of simple and columnar epithelial cells and is surrounded by uterine/endometrial glands. Uterine functional development occurs postnatally in rodents, starting at PND 1-3 [75], which is equivalent to human uterine development at around gestational week 14 [76]. At birth, in rodents, the uterus does not have endometrial glands but their rudiments develop by about PND 5 and becomes apparent by PND 7-9. Subsequently the glands extend into the stroma and myometrium and become organized into bundles and are fully developed by the second week after birth [77 - 79]. Numerous signaling pathways such as the WNT and HOX pathways are involved in the uterine formation, patterning and organogenesis [80 - 82]. However postnatal uterine function is dependent on the coordinated induction of several growth factors, cytokines and their receptors (e.g., IGF-1, FGF, activin/follistatin signaling) in addition to estrogen signaling [83 - 85]. In fact, these signaling pathways are highly responsive to and augment the estrogen signaling. Thus developmental and functional uterine stages are prone to EDCs' actions.

\subsection{Expression Patterns and Roles of ERs in the Ovaries and Uteri}

Most estrogenic EDCs have been shown to activate genomic or non-genomic estrogen signaling. These actions are mediated via the endogenous ERs (ESR1 and ESR2) in the ovary and uterus. Thus the ubiquitous expression of ERs in multiple reproductive tissues make them prone to the actions of EDCs. ESR1 and ESR2 are expressed in early folliculogenesis in a cell and stage specific manner in several species, including primates, cattle, rats, and mice [25, 86 - 89]. ESR1 is expressed primarily in theca cells, and ESR2 is expressed in granulosa cells and essential for FSH-directed granulosa cell differentiation as well as for LH responsiveness [90, 91]. ESR2 also facilitates mechanisms that promote follicle maturation from the early antral to the preovulatory stages [92, 93]. In addition it may play a major role in primordial follicle formation in the ovary [93 - 97]. In contrast, although ESR1 plays a role in the regulation of theca cell steroidogenesis in the ovary, its main function is to mediate estrogen-regulated feedback in the hypothalamus and pituitary $[98,99]$. On the other hand, very little is known about non-genomic estrogen signaling that is mediated by membrane bound ESR1 (mESR1) in the ovary but recent evidence has demonstrated a role for PI3K/AKT signaling downstream of potential mESR1 activation in the ovary [25, 100].

In the uterus, ERs are actively expressed during Mullerian duct development and are seen as early as E13 in the mesenchyme, while the uterine epithelium expresses ERs soon after birth [101]. Interestingly, uterine development is estrogen-independent during neonatal development. However the presence of ERs makes the uterus susceptible to the actions of EDCs. The predominant ER receptor in the uterus is ESR1; using KO studies, it has been demonstrated that ESR1 disruption causes hypoplastic uteri [90, 102]. It is expressed in both the luminal and glandular epithelial compartments.

\section{EPIDEMIOLOGICAL EVIDENCE FROM HUMANS SUPPORTING INVOLVEMENT OF EDCS IN FEMALE REPRODUCTIVE DISEASE AND IN VIVO STUDIES WITH EDC EXPOSURES IN RODENT MODELS}

\subsection{Diethylstilbestrol (DES)}

For about 30 years between the 1940s and the 1970s, DES, a nonsteroidal synthetic estrogen was prescribed at doses of 5-150 mg/day, to pregnant women at risk of miscarriage. The most convincing human evidence that estrogenic EDC exposure during development can permanently affect female reproduction, comes from the reports that followed [103]. Numerous abnormalities in the reproductive, cardiovascular, and immune systems have since been reported in both male and female offspring of women treated with DES, and similar effects have been demonstrated in animal models (reviewed in [104]). These effects are being observed in the granddaughters of DES-treated women as well [105, 106]. While DES caused vaginal clear cell adenocarcinoma in only $0.1 \%$ of the female offspring, over $95 \%$ reported reproductive tract dysfunction and poor pregnancy outcomes [107, 108]. There is evidence of multi-generational effects and epigenetic mechanisms have been implicated [109 - 112].

\subsection{DES in vivo Studies}

Mice injected with a single dose of $10 \mu \mathrm{g} / \mathrm{kg}$ DES on E15 and examined at 7 months of age had no CL and numerous atretic follicles [113]. They were also found to have vacuolated interstitial tissue with lipid droplet inclusions. 
Other studies with vary doses of DES ( $5 \mu \mathrm{g} / \mathrm{kg}$ to $100 \mu \mathrm{g} / \mathrm{kg}$ ) administered either in utero (E9-E16) [114], or neonatally (PND 1-5) [115], demonstrated that adult DES ovaries developed similar hypertrophy and vacuolation of interstitial tissue, hemorrhagic cysts and lack of corpora lutea. These animals also had high levels of testosterone [114]. There was a dose-dependent reduction in the number of the litters as well as the number of oocytes ovulated after stimulation with exogenous gonadotropins [116]. The oocytes derived from such treated ovaries and used in IVF showed lower levels of fertilizability, suggesting reduced oocyte quality [117 - 119]. However, $5 \mu \mathrm{g}$ /day DES-treated ovaries transplanted into untreated ovariectomized host mice were able to give rise to normal female offspring that in turn gave birth to normal size litters and had normal uterine morphology, suggesting that the DES treatment effects were not mediated via germ cells [120].

DES can bind to both ERs with many fold higher affinity than estradiol [94]. Multiple studies from Iguchi and colleagues showed that in utero (E15-18) and neonatally (PND 1-5) DES-treated mice had ovaries containing excessive number of MOFs by adulthood [121, 122]. MOFs were also observed in ovaries that were treated in vitro at PND 1-5, following their transplantation to untreated mice, suggesting a direct effect of DES in the ovary [122]. Recent studies showed that neonatal exposure to $3 \mu \mathrm{g} / \mathrm{kg}$ DES induced MOFs, a process mediated by ESR2 and not ESR1 [97]. DES exposure was shown to reduce oocyte apoptosis (potentially suppressing oocyte nest breakdown) via ESR2 signaling mechanisms. Furthermore, it was hypothesized that such alterations in the germ cell and somatic cell populations may affect the invasion of pregranulosa cells and basement membrane remodeling during primordial follicle formation [60]. Interestingly, the incidence of MOFs has been reported with other EDC exposures as well (see below, [96]).

It is well known that DES caused T-shaped uteri and clear cell adenocarcinoma of the uterus, cervix, and vagina in women whose mothers were exposed to DES during pregnancy [123]. Such observations have been replicated in the progeny of DES-treated mice that show malformations of the uterus, squamous metaplasia of the luminal and glandular epithelium, endometrial hyperplasia and leiomyomas, and oviductal proliferative lesions [124, 125]. Ovariectomized animals when supplemented with estradiol are able to respond by a transient increase in gene expression and concomitant uterine proliferation and growth [126 - 128]. When such a stimulus is removed, the uterus returns to its unstimulated state. However, when DES or estradiol is administered during neonatal development, expression of immediate early genes such as lactoferrin, EGF, and proto-oncogenes such as $c$-fos, $c$-jun, and $c$-myc is upregulated even into adulthood [126, 129, 130]. Inversely, expression of genes that are necessary for uterine development, such as the Abdominal B (AbdB) Hox gene, Hoxa-10, (known to be controlled by estradiol and progesterone, [131]), Wnt7a as well as Msx2 are repressed leading to structural abnormalities of the reproductive tract [132 - 135]. Numerous studies have been conducted to assess the methylation patterns of promoters of several of these estrogen-responsive genes associated with uterine development.

Neonatal DES exposure in mice caused $\sim 90 \%$ incidence of epithelial cancers of the uterus by 18 months of age [136]. Furthermore, the promoter region of the lactoferrin gene was found to be hypomethylated in the adult uterus. However, if the animals were exposed for the same length of time during adulthood, no such DNA methylation or expression defects were observed [137]. Subsequently, it was also found that exon 4 of the $c$-fos gene was extensively hypomethylated while the promoter region and intron 1 was unaffected, thereby potentially allowing for the upregulation of $c$-fos expression [138]. QPCR studies performed by Sato and colleagues examining the expression of Dnmts in neonatally DES exposed C57BL/6 mice, revealed that expression of Dnmt1 and Dnmt $3 b$ was decreased at PND5 in DES-treated mice, and the pattern continued until PND14 [139]. Interestingly, it was found that human leiomyoma samples had alterations in the levels of Dnmts as well, with concomitant global hypomethylation [140].

DES down-regulates Hoxa gene expression akin to the effects associated with uterine abnormalities found in Hoxa KO mice. The predominant phenotype is the loss of boundary between the oviduct and uterus. It has been shown that the anterior to posterior specific pattern of Hoxa-9 is essential for the normal development and function of the uterus and that DES causes a posterior shift of Hoxa-9 and Hoxa-10 expression and homeotic anterior transformations [132]. A recent report by Bromer and colleagues has shown that after in utero (E9-16) exposure to $10 \mu \mathrm{g} / \mathrm{kg} \mathrm{DES}$, there is hypermethylation in the promoter and intron 1 regions of Hoxa-10 gene, in the caudal part of the uterus with a concomitant increase in the Hoxa-10 expression in the same region [141]. Recent reports have suggested that cell fate decisions are altered due to exposure DES.

Interesting new studies have now provided a link between mESR1 signaling and regulation of histone modifications. It was found that rapid PI3K/AKT signaling downstream of membrane-associated ER, in response to estradiol as well as DES, caused reduction in trimethylation of $\mathrm{H} 3 \mathrm{~K} 27$, a repressive histone mark. More interestingly, activation of this nongenomic signaling caused reprogramming of the uterine gene expression profile [46, 142]. It has 
also been found that neonatal DES exposure temporarily alters expression of multiple chromatin-modifying proteins and persistently alters epigenetic marks in the adult uterus at the sine oculis homeobox 1 locus which along with lactoferrin (see above) is an estrogen responsive gene whose expression is persistently upregulated [38].

\subsection{Methoxychlor (MXC)}

Methoxychloris a well-studied organochlorine pesticide that is used as a replacement for DDT. It is an estrogenic compound that demonstrates low-affinity binding for estrogen receptors [143]. The major MXC metabolites, HPTE and mono-OH MXC, can function as estrogenic, anti-estrogenic, or anti-androgenic compounds [144], and therefore it is used as a model compound [145]. Epidemiological studies have shown that there is a strong association between developmental exposure to organochlorine pesticides and underdeveloped fetuses and subsequent female fertility problems [146]. For example, presence of $p^{\prime} p$ '-DDT in the mothers' serum 1-3 days after their daughters' birth is associated with a longer time of pregnancy (TPP) as well as with a reduced probability of pregnancy and high infertility [147]. A two to threefold increase in risk of prolonged time-to-pregnancy and spontaneous abortion, among female greenhouse workers $[13,148]$ and increased infertility in women with agricultural work histories has also been noted [149].

\subsection{Methoxychlor in vivo Studies}

Adverse effects that were observed in these association studies are similar to the effects observed in experimental animals exposed to MXC during adulthood. Exposure to MXC (2500 or $5000 \mathrm{ppm}$ ) interfered with the normal estrous cycle, reduced mating rate and litter size [150]. However, when the exposure was withdrawn, these animals reverted to regular estrous cycles. In general, this observation applies to most other estrogenic EDCs as well. Further studies demonstrated that adult mice or rats that were exposed to MXC showed persistent vaginal estrus [151], direct inhibition of embryonic growth, implantation failure [152], pregnancy loss [153], and ovarian atrophy due to inhibition of folliculogenesis leading to atretic follicles and reduced ovulation and decreased numbers of CL [151, 154, 155]. It was shown that exposure to MXC in adult mice selectively affects the antral follicles and induces atresia using the Bcl2/Bax signaling pathway, without affecting the HPG axis [156].

In contrast, when the exposure periods included in utero and early postnatal development period, the effects lasted into adulthood with more severe outcomes on reproductive parameters in rats. These included acceleration of the vaginal opening (sign of puberty), acceleration of the onset of the first estrus, irregular cycles with persistent vaginal estrus, reduced pregnancy rate and litter size despite apparent mating, and early reproductive senescence [157 - 159]. Serum estradiol and progesterone levels were altered with increased FSH levels [158]. The effects on the ovary were dramatic, with both folliculogenesis and ovulation being inhibited.

In a more recent study, female rats were treated during fetal and neonatal development (E19-PND 7) with a dose of MXC that is comparable to the dose used in the above studies $(100 \mathrm{mg} / \mathrm{kg} / \mathrm{day})$ the exposed females displayed similar abnormalities in reproductive parameters as well as in ovarian morphology by adulthood [160]. A close examination of follicle composition showed that developmental MXC treatment did not affect the total number of follicles or follicles at primary and secondary stages in adult females. However, the number of preantral and early antral follicles was increased and the number of CL was reduced, with numerous large cystic follicles. Immunohistochemical staining and quantification of expression patterns of important regulators of ovarian functions revealed that while LHR, CYP11A1, and CYP19A1 levels were reduced, levels of AMH and AR were increased, and levels of StAR and ESR1 were unchanged [160]. Especially noteworthy was that ESR2 level was unchanged in primary and secondary follicles, yet decreased dramatically in peri-antral stage follicles, which are responsive to gonadotropins. These observations suggest that hormone-responsive follicles are most affected by EDC exposure.

Epigenetic analyses using bisulfite-sequencing PCR and methylation-specific PCR showed that MXC caused hypermethylation in multiple CpGs in two CPG islands in ESR2 promoter sequences while it had no effect on DNA methylation levels in the ESR1 promoter at PND 60 [24]. This finding correlates with the lack of significant effects on the levels of ESR1 protein in the adult ovary [24, 160]. Further analysis has shown that the DNA methylation levels in the promoter regions of these genes were unchanged in neonatal ovaries (PND 7) immediately after the exposure [25]. These data demonstrate the age-dependence/hormone responsiveness of the epigenetic changes, which has also been shown in other tissues (e.g., uteri) with other compounds (e.g., DES, genistein) [161]. The global DNA methylation analysis using AP-PCR showed that there were multiple loci that were hypermethylated in MXC-treated ovaries [24]. The majority of candidates were those encoding transcription factors or ribosomal proteins. One candidate that was 
shown to be hypermethylated in multiple MXC-treated samples was an endopeptidase encoded by $P A P P-A$ locus [24]. Reduced PAPP-A activity due to increased methylation could limit its availability in follicles and thus increase IGFBP content and sequester IGF-1. This could lead to the observed defect in follicle selection and maturation [160]. Interestingly, in the same set of studies, exposure to a low dose of MXC ( $20 \mu \mathrm{g} / \mathrm{kg} / \mathrm{day})$ caused a significant increase in the expression of AMH [160] and multiple methylation events both in the ESR2 promoter sequences and the PAPP-A locus [24]. There was a significant upregulation in ESR2 expression in the granulosa cells of multiple stages of follicles at PND 7, similar to high-dose MXC-treated follicles. While these epigenetic alterations did not cause any functional defects in the low dose-MXC treated females, the high dose-MXC treated animals had the characteristic ovarian dysfunction. A more recent targeted genome-wide methylation array study has revealed that members of essential signaling pathways are hypermethylated and their gene expression down-regulated in MXC-treated ovaries. IGF-1 signaling was the most significantly affected pathway wherein several members of the family - Igflr, insulin receptor (Insr), Pik3r1, Hras, and Foxo3 - were hypermethylated [25]. These data suggested that the initial DNA methylation patterns were representative of the gene expression patterns responsive to the EDC exposure and not the adult hypermethylation events. Furthermore, the long-lasting effects observed by PND 60 could be due to histone modifications. Unpublished data from our laboratory has shown that histone trimethylation, H3K9me3, an inhibitory histone mark, is increased in antral follicles of MXC-treated ovaries suggesting suppression of stage-specific gene expression thus disallowing antral follicle progression to ovulation.

Uterotrophic effects of MXC are well established [162]. MXC increases uterine wet weight, proliferation and protein secretion [163, 164]; these effects have been attributed to its estrogenic actions [152, 165 - 169]. In some cases, MXC can interfere with or differ from the actions of estradiol [151]; this was also reported in other experimental systems [22, 170, 171]. More recently, it was shown that in vivo, neonatal MXC exposure inhibits Hoxa-10 expression in the adult uterus in mice and interferes with the binding of estradiol to ERE of Hoxa-10 [172]. Although a potential epigenetic mechanism was suggested, confirmation of this possibility awaits future studies [53].

\subsection{Genistein}

The use and consumption of soy products is ubiquitous. However the isoflavonoid phytoestrogen, genistein, derived from soy products has been shown to have endocrine-disrupting potential in domestic species: newborn lambs born to ewes fed clover had reproductive abnormalities (in the late 1940s [173]). United States FDA has approved 25g/day soy consumption, approximately equivalent to $75 \mathrm{mg}$ of isoflavones/day ( $1 \mathrm{mg} / \mathrm{kg} /$ day), as being beneficial against coronary artery disease (FDA, 1999). However, a cause for concern is that babies who are fed soy formula consume on average of 6-9 $\mathrm{mg} / \mathrm{kg}$ body weight, which would result in babies being exposed to 4-7 times higher amounts of soy as compared to adults that are on a soy-rich diet or as per FDA guidelines [174, 175]. Early life exposure to soy formula is associated with a greater risk of uterine fibroids in adulthood among other conditions $[176,177]$.

\subsection{Genistein in vivo Studies}

Neonatal administration of $0.5-50 \mathrm{mg} / \mathrm{kg}$ genistein (PND1-PND5) caused an increase in ano-genital distance (masculinization), accelerated puberty, and irregular estrous cycles in adult CD-1 mice [178]. In this context, genisteintreated $(50 \mathrm{mg} / \mathrm{kg} / \mathrm{d})$ mice exhibited defects in the ovary such as the MOF phenotype, which correlated with a reduction in the number of apoptotic oocytes, previously shown to involve ESR2 mediated actions [48, 95, 96]. This was also associated with fewer pups born to these females over their shortened reproductive lifespan [179, 180]. Genistein and other phytoestrogens have been shown to readily cross the placenta [181] and exposure in utero between E15 and E19 has shown similar effects as mentioned above [182]. A most recent report on the oral administration of genistin (the glycosylated form of genistein) revealed that exposure between PND1-5 also resulted in ovaries with MOFs, delayed puberty, irregular estrous cycles and reduced litter sizes [183]. It has been demonstrated that the estrogenic action of genistein is mediated via ER-mediated pathways [93, 184].

Numerous uterine defects have been documented in CD-1 mice that were neonatally exposed (PND1-5) to genistein (50 mg/kg/day) [178, 185, 186] supporting epidemiological data from women who were soy-fed as babies that had irregular menstrual cycle lengths and pain during cycles or uterine fibroids $[176,187]$. A recent paper showed that the oocytes are themselves competent for fertilization and early embryonic development, but the uteri are unable to support viable implantations: the sites were smaller and fewer in number [188]. Another study has shown that genistein induces fluid accumulation in the uterus in ovariectomized rats via ER signaling and the cystic fibrosis transmembrane regulator [189]. These results not only confirm the effect of genistein as an EDC but also shed light on the mechanism of fluid 
retention, in this case, as a therapy for menopausal conditions.

Tang and colleagues recently investigated whether neonatal DES/genistein exposure could cause epigenetic changes and alter gene expression in adult uteri and whether there are interactions between adult ovarian hormones and such epigenetic reprogramming. CD-1 mice were exposed to DES $(1 \mu \mathrm{g}$ and $1000 \mu \mathrm{g} / \mathrm{kg})$ or genistein $(50 \mathrm{mg} / \mathrm{kg})$ from PND1-5. Subsequently, some animals were sacrificed at PND19 while others were aged to 6 and 18 months with or without ovariectomies. Genome-wide methylation analysis was conducted with MSRF and candidate genes were identified. Of interest was the nucleosomal binding protein 1 (Nsbpl), which was shown to be hypomethylated at PND19 and hypermethylated by puberty, in the control. Low-dose DES and genistein treated $v$ s. high-dose DES-treated animals had opposing methylation patterns. Furthermore, it was shown that in the aged animals, both DES and genistein caused hypermethylation in the ovariectomized animals but remained hypomethylated in non-ovariectomized animals. These data suggest that Nsbpl is hypermethylated in intact mice with age and that DES and genistein have opposing effects on the methylation patterns in intact vs. ovariectomized aging animals (hypomethylation $v s$. hypermethylation), respectively. These studies highlighted the age-dependent aspect of epigenetic reprogramming and also its interaction with steroid hormones [161].

\subsection{Bisphenol A (BPA)}

Bisphenol A is a high-volume plasticizer whose total worldwide production exceeds 6 million tons per year [190]. Used in the manufacture of polycarbonate plastics and epoxy resins, exposure can occur via plastic food containers (especially when heated or microwaved), food and drink cans, baby bottles, and carbonless paper (reviewed in [191, 192]). As a result, 95\% of adults who were tested have detectable levels of BPA in their urine [193].

Infants in neonatal intensive care units have particularly high exposure to BPA, presumably from its use in medical devices and from the migration of BPA into infant formula from the container. It has also been found in detectable amounts in dust [193 - 196]. Urine BPA levels of women undergoing infertility treatment is negatively correlated with the number and quality of eggs retrieved, and with serum $\mathrm{E}_{2}$ levels $[197,198]$. BPA has been shown to have estrogenic properties and that it can be transferred both lactationally and transplacentally [190, 199]. BPA has a lower binding affinity to ERs than estradiol or DES [94, 200]. A major concern is that the "safe" exposure limit for BPA is 50 $\mu \mathrm{g} / \mathrm{kg} /$ day but studies with lower doses than the "safe" dose demonstrated numerous detrimental defects in the female reproductive system [190].

\subsection{BPA in vivo Studies}

Perinatal exposure to low environmentally relevant BPA doses $(25-250 \mathrm{ng} / \mathrm{kg})$ caused accelerated puberty, altered estrous cyclicity and disrupted ovarian morphology associated with changes in body weight and LH levels [201 - 203]. An increased occurrence of ovarian cysts with blood filled bursae, abnormal numbers of antral follicles, and decreased $\mathrm{CL}$ was found in aged mice that were neonatally exposed to a $100 \mu \mathrm{g} / \mathrm{kg}$ dose of BPA [204]. Another study demonstrated that exposure of rats to $50 \mu \mathrm{g} / \mathrm{kg}$ and $50 \mathrm{mg} / \mathrm{kg}$ doses during the period of hypothalamic neuronal establishment (PND0-3), resulted in a reduction in CL and increase in MOF and hemorrhagic follicles confirming that BPA has direct effects on the ovary that are independent of GnRH neuronal activity [205]. MOFs were also observed in studies with neonatal BPA exposure (150 $\mu \mathrm{g} / \mathrm{kg}$ dose), in mice [206].

Another effect of BPA is exerted at the level of oogenesis and is of very high concern [197]. Studies from Hunt and colleagues demonstrated that BPA released from damaged animal cages and water bottles, which were inadvertently treated with harsh alkaline detergent, induced defects in the meiotic prophase stage of oocyte development in mice: oocytes had increased levels of meiotic aneuploidy due to congression failure. This effect was mimicked when cages were intentionally damaged, or when 20 to 22 day old mice were exposed to a similar dose of BPA ( $20 \mathrm{ng} / \mathrm{g}$ body weight) for as few as 7 days [207]. Further studies demonstrated that BPA caused defects in synapsis and recombination in the homologous chromosomes in the fetal ovary. Interestingly, $\beta E R K O$ animals exhibited very similar meiotic defects in the pachytene oocytes of their fetal gonads. In utero treatment of $\beta E R K O$ females with low doses of BPA did not enhance the oocyte defects, suggesting that BPA could act via the ESR2 signaling pathway alongside other nongenomic mechanisms [208]. In ArKO mice that were given BPA ( 0.1 or $1.0 \% \mathrm{w} / \mathrm{w}$ in chow), the ovarian expression of IGF-I, IGF-I receptor, GDF9, and BMP-15 were increased to normal levels, an effect resembling that of ArKO mice given estradiol replacement [209]. These authors further reported that BPA exerted "little effect" within ovarian and other estradiol-dependent tissues of wild-type mice.

In the uterus, neonatal BPA exposure has been shown to cause long-term adverse effects, including cystic 
endometrial hyperplasia, as well as the occurrence of more serious uterine pathologies such as adenomyosis, leiomyomas (fibroids), atypical hyperplasia, and stromal polyps [204]. Furthermore, paraovarian cysts, progressive proliferative lesions of the oviduct, and cystic mesonephric (Wolffian) duct remnants in the uterus were found in the BPA-treated mice after in utero exposure [210]. Similar defects were shown in in utero BPA-exposed mice (25 to 250 $\mathrm{ng} / \mathrm{kg}$ ), using Alzet osmotic pumps [203]. Vaginal wet weight was decreased and lamina propria of the endometrium was decreased as well, with concomitant increase in glandular epithelial proliferation at 3 months of age. BPA caused an increase in ESR1 and PR expression in the lumina typifying a hyper-estrogenic response of the uterus. It would be of interest to examine if hypomethylation is associated with such an increase in gene expression. A recent study by Varayoud and colleagues showed that in an ovarectomized, neonatally BPA or DES exposed mouse model, progesterone priming followed by estradiol treatment caused an impaired proliferative response and altered PR and ESR1 expression in the sub-epithelial stroma of the uterus suggesting that the uteri were unable to respond to ovarian steroids [211]. In addition, Hoxa-10 expression was decreased even though methylation of its promoter was unaffected. Furthermore, an abnormal overexpression of the corepressor, silencing mediator for retinoic acid and thyroid hormone receptor (SMRT), was found in the same stromal cells in which Hoxa-10 expression was reduced. Other epigenetic analyses on BPA-treated uteri from 2-6 week old mice after E9-E16 exposure to $5 \mathrm{mg} / \mathrm{kg}$ BPA were performed by Bromer et al. (2010). They demonstrated a decrease in DNA methylation of the promoter and intron regions of Hoxa-10. This group also found that the hypomethylation allowed for increased ESR1 binding to the EREs present in the Hoxa-10 promoter thereby allowing the uteri to become hyper-responsive to estrogen/BPA signaling [212].

\subsection{Di-ethylhexyl phthalate (DEHP)}

Phthalate esters are ubiquitous in our environment and used as plasticizers to give flexibility to PVC-derived plastics [213]. Di-ethylhexyl phthalate is one of the most widely used phthalate ester [214] and present in medical bags and tubings, packaging, and food containers. It is non-covalently bound to plastics, and can leach out of these products, resulting in potential daily human exposure in the range of 3-30 $\mu \mathrm{g} / \mathrm{kg} /$ day [213]. In fact DEHP and its metabolites have been found in breast milk, serum, amniotic fluids and sweat [215,216] and recently in urine samples from mothers and infants [217]. One the most vulnerable populations are infants in neonatal intensive care units or NICUs, whose daily exposure reaches $22.6 \mathrm{mg} / \mathrm{kg}$ [213]. The developmental exposure to DEHP is of special concern. In humans, in utero DEHP exposures were associated with shorter pregnancy duration [218] and a shortened anogenital distance (AGD) and index in boys [219, 220]. Increased incidences of miscarriage were reported in women occupationally exposure to high dose of phthalates [221]. Danish girls with high urinary concentration of phthalate metabolites, including DEHP show delayed puberty [222].

\subsection{DEHP and in vivo Studies}

Animals that are exposed to DEHP during adulthood and peripubertal periods show adverse effects in multiple reproductive parameters, such as estrous cyclicity, pubertal age, litter size, and alterations in serum hormone levels and ovarian morphology [223 - 225]. Transient daily oral exposures to $2 \mathrm{~g} / \mathrm{kg}$ of DEHP in female rats result in prolonged estrous cycles, and delay or suppression in natural ovulation time resulting in reduced number of ovulations and hence absence of CL. Suppressed serum levels of estradiol, progesterone, and LH were also found. The primary cause of these disruptions appears to be the low levels of estradiol, insufficient to induce preovulatory LH surge [226, 227]. Studies with cultured ovarian follicles suggest that DEHP acts via its more active metabolite MEHP and inhibits FSHstimulated cAMP production, thereby preventing activation of the enzymes for progesterone production, and suppresses levels of Cyp19al via activation of PPARs. Prolonged exposures to a lower dose $(0.05 \mathrm{mg} / \mathrm{kg} / \mathrm{day})$ of DEHP resulted in reduced expression of Cyp17a1, Cyp19a1, progesterone receptor (Pgr), Lhcgr and Fshr in the adult ovary (PND41) of the CD-1 mice, all which may affect ovarian steroidogenesis [228]. Besides suppressed ovarian steroid production, multiple studies have reported altered follicular dynamics as one of the major consequences of DEHP exposure. These alterations include accelerated follicular recruitment and failure in follicular maturation and ovulation. Early postnatal (PND 5-20) exposure in mice to relatively low levels of DEHP depletes primordial follicles while increasing the number secondary and antral follicles [229], which is associated with altered pattern of imprinted genes and increased metaphase II spindle abnormalities. Follicular dynamics were similarly altered in adult mice that were transiently (10-30 days) exposed to DEHP (200 $\mu \mathrm{g} / \mathrm{kg}$ to $700 \mathrm{mg} / \mathrm{kg})$, which was associated with dysregulation of PI3K signaling pathway [234]. Studies have also suggested that DEHP exposure inhibits follicular maturation which may be a result of the inhibition of antral follicle growth due to increased oxidative stress leading to increased apoptosis [230]. Most of the studies described above have employed extended exposure periods and larger doses. Therefore, studies with 
environmentally relevant doses of DEHP specifically targeting the fetal and neonatal ovarian development are needed.

In the uteri, exposures to DEHP during early pregnancy lead to adverse outcomes. Rats that were exposed to oral DEHP (313 and $573 \mathrm{mg} / \mathrm{kg} /$ day) between E0-20 had reduced number of pups in their litters as well as decreased mean pups weights. Similarly mice that were exposed to $\operatorname{DEHP}(0,44,91,191$, and $293 \mathrm{mg} / \mathrm{kg} / \mathrm{day})$ between E0-17 showed a dose-dependent increase in number of embryonic resorptions as well as other major malformations, including cardiovascular malformation and skeletal defects with the two highest doses [231]. More recently, a shorter exposure to $\operatorname{DEHP}(0,250,500$, and $1000 \mathrm{mg} / \mathrm{kg} /$ day $)$ during first 4 to 6 days of pregnancy, in mice, showed that the highest dose leads to extensive embryonic resorption at the end of exposure period, due to reduced endometrial receptivity (characterized by insufficient decidualization), which is associated with an increase in ESR1, PR, and E-cadherin and inhibition of MAPK and Nf- $\mathrm{KB}$ signaling pathways [232]. Interestingly, the DEHP exposure ( $405 \mathrm{mg} / \mathrm{kg} / \mathrm{day})$ between E6 and PND 21, that resulted in increased antral follicular atresia, did not affect uterine luminal epithelial height [233]. The exact mechanisms of the adverse effects of DEHP on the uterus and embryo are not known, and require further investigations. In addition, it is worth noting that the effects of DEHP are not likely mediated by estrogen receptor as DEHP shows little or no uterotrophic effects in vivo, although DEHP binds to estrogen receptor.

\section{CONCLUSION}

There is a large amount of evidence that demonstrates the adverse effects of EDCs on female reproductive health. Exposures in early ovarian and uterine developmental stages have irreversible, long-term effects on the reproductive function proving that developmental reprogramming occurs after EDC exposures. Epigenetic mechanisms mediate some of these EDC actions and comprehensive genome-wide studies are necessary to deduce the details.

\section{CONFLICT OF INTEREST}

The authors confirm that this article content has no conflict of interest.

\section{ACKNOWLEDGEMENTS}

The studies cited from the authors' laboratories were supported in part by National Institute of Environmental Health Science grants (ES013854, ES017059, and ES017847) and NIEHS Center grant ES005022.

\section{REFERENCES}

[1] Ohe T, Watanabe T, Wakabayashi K. Mutagens in surface waters: a review. Mutat Res 2004; 567(2-3): 109-49. [http://dx.doi.org/10.1016/j.mrrev.2004.08.003] [PMID: 15572284]

[2] Abnet CC. Carcinogenic food contaminants. Cancer Invest 2007; 25(3): 189-96. [http://dx.doi.org/10.1080/07357900701208733] [PMID: 17530489]

[3] Hamra GB, Guha N, Cohen A, et al. Outdoor particulate matter exposure and lung cancer: a systematic review and meta-analysis. Environ Health Perspect 2014; 122(9): 906-11.

[PMID: 24911630]

[4] Jeon GH, Kim SH, Yun SC, Chae HD, Kim CH, Kang BM. Association between serum estradiol level and coronary artery calcification in postmenopausal women. Menopause 2010; 17(5): 902-7. [http://dx.doi.org/10.1097/gme.0b013e3181d76768] [PMID: 20512078]

[5] Rannevik G, Jeppsson S, Johnell O, Bjerre B, Laurell-Borulf Y, Svanberg L. A longitudinal study of the perimenopausal transition: altered profiles of steroid and pituitary hormones, SHBG and bone mineral density. Maturitas 1995; 21(2): 103-13. [http://dx.doi.org/10.1016/0378-5122(94)00869-9] [PMID: 7752947]

[6] Cummings SR, Browner WS, Bauer D, et al. Endogenous hormones and the risk of hip and vertebral fractures among older women. N Engl J Med 1998; 339(11): 733-8.

[http://dx.doi.org/10.1056/NEJM199809103391104] [PMID: 9731089]

[7] van der Stege JG, Groen H, van Zadelhoff SJ, et al. Decreased androgen concentrations and diminished general and sexual well-being in women with premature ovarian failure. Menopause 2008; 15(1): 23-31. [http://dx.doi.org/10.1097/gme.0b013e3180f6108c] [PMID: 18257141]

[8] Crain DA, Janssen SJ, Edwards TM, et al. Female reproductive disorders: the roles of endocrine-disrupting compounds and developmental timing. Fertil Steril 2008; 90(4): 911-40.

[http://dx.doi.org/10.1016/j.fertnstert.2008.08.067] [PMID: 18929049]

[9] Schug TT, Janesick A, Blumberg B, Heindel JJ. Endocrine disrupting chemicals and disease susceptibility. J Steroid Biochem Mol Biol 2011; 127(3-5): 204-15.

[http://dx.doi.org/10.1016/j.jsbmb.2011.08.007] [PMID: 21899826] 
[10] Cao LL, Yan CH, Yu XD, et al. Relationship between serum concentrations of polychlorinated biphenyls and organochlorine pesticides and dietary habits of pregnant women in Shanghai. Sci Total Environ 2011; 409(16): 2997-3002. [http://dx.doi.org/10.1016/j.scitotenv.2011.04.040] [PMID: 21665017]

[11] Younglai EV, Holloway AC, Foster WG. Environmental and occupational factors affecting fertility and IVF success. Hum Reprod Update 2005; 11(1): 43-57. [http://dx.doi.org/10.1093/humupd/dmh055] [PMID: 15601728]

[12] Bradman AS, Schwartz JM, Fenster L, Barr DB, Holland NT, Eskenazi B. Factors predicting organochlorine pesticide levels in pregnant Latina women living in a United States agricultural area. J Expo Sci Environ Epidemiol 2007; 17(4): 388-99. [http://dx.doi.org/10.1038/sj.jes.7500525] [PMID: 17033681]

[13] Bretveld R, Zielhuis GA, Roeleveld N. Time to pregnancy among female greenhouse workers. Scand J Work Environ Health 2006; 32(5): 359-67. [http://dx.doi.org/10.5271/sjweh.1031] [PMID: 17091203]

[14] Guzick DS, Swan S. The decline of infertility: apparent or real? Fertil Steril 2006; 86(3): 524-6. [http://dx.doi.org/10.1016/j.fertnstert.2006.05.027] [PMID: 16952501]

[15] Ventura SJ, Curtin SC, Abma JC, Henshaw SK. Estimated pregnancy rates and rates of pregnancy outcomes for the United States, $1990-2008$. Natl Vital Stat Rep 2012; 60(7): 1-21. [PMID: 22970648]

[16] Diamanti-Kandarakis E, Bourguignon JP, Giudice LC, et al. Endocrine-disrupting chemicals: an Endocrine Society scientific statement. Endocr Rev 2009; 30(4): 293-342.

[http://dx.doi.org/10.1210/er.2009-0002] [PMID: 19502515]

[17] Bergman A, Heindel JJ, Kasten T, et al. The impact of endocrine disruption: a consensus statement on the state of the science. Environ Health Perspect 2013; 121(4): A104-6. [http://dx.doi.org/10.1289/ehp.1205448] [PMID: 23548368]

[18] Louis BG, Cooney MA, Peterson CM. The ovarian dysgenesis syndrome. J Dev Orig Health Dis 2011; 2(1): 25-35. [http://dx.doi.org/10.1017/S2040174410000693]

[19] Guillette LJ Jr, Gross TS, Masson GR, Matter JM, Percival HF, Woodward AR. Developmental abnormalities of the gonad and abnormal sex hormone concentrations in juvenile alligators from contaminated and control lakes in Florida. Environ Health Perspect 1994; 102(8): 680-8. [http://dx.doi.org/10.1289/ehp.94102680] [PMID: 7895709]

[20] Moore BC. Altered sex hormone concentrations and gonadal mRNA expression levels of activin signaling factors in hatchling alligators from a contaminated Florida lake. J Exp Zool A Ecol Genet Physiol 2010; 313(4): 218-30.

[21] Schmitt CJ, Hinck JE, Blazer VS, et al. Environmental contaminants and biomarker responses in fish from the Rio Grande and its U.S. tributaries: spatial and temporal trends. Sci Total Environ 2005; 350(1-3): 161-93. [http://dx.doi.org/10.1016/j.scitotenv.2005.01.038] [PMID: 16227080]

[22] Pickford DB, Morris ID. Effects of endocrine-disrupting contaminants on amphibian oogenesis: methoxychlor inhibits progesterone-induced maturation of Xenopus laevis oocytes in vitro. Environ Health Perspect 1999; 107(4): 285-92. [http://dx.doi.org/10.1289/ehp.99107285] [PMID: 10090707]

[23] Riana Bornman MS, Bouwman H. Environmental pollutants and diseases of sexual development in humans and wildlife in South Africa: harbingers of impact on overall health? Reprod Domest Anim 2012; 47(Suppl. 4): 327-32. [http://dx.doi.org/10.1111/j.1439-0531.2012.02094.x] [PMID: 22827388]

[24] Zama AM, Uzumcu M. Fetal and neonatal exposure to the endocrine disruptor methoxychlor causes epigenetic alterations in adult ovarian genes. Endocrinology 2009; 150(10): 4681-91 [http://dx.doi.org/10.1210/en.2009-0499] [PMID: 19589859]

[25] Zama AM, Uzumcu M. Targeted genome-wide methylation and gene expression analyses reveal signaling pathways involved in ovarian dysfunction after developmental EDC exposure in rats. Biol Reprod 2013; 88(2): 52. [http://dx.doi.org/10.1095/biolreprod.112.104802] [PMID: 23303685]

[26] Cantone I, Fisher AG. Epigenetic programming and reprogramming during development. Nat Struct Mol Biol 2013; 20(3): $282-9$. [http://dx.doi.org/10.1038/nsmb.2489] [PMID: 23463313]

[27] Reik W, Dean W, Walter J. Epigenetic reprogramming in mammalian development. Science 2001; 293(5532): 1089-93. [http://dx.doi.org/10.1126/science.1063443] [PMID: 11498579]

[28] Hajkova P, Erhardt S, Lane N, et al. Epigenetic reprogramming in mouse primordial germ cells. Mech Dev 2002; 117(1-2): 15-23. [http://dx.doi.org/10.1016/S0925-4773(02)00181-8] [PMID: 12204247]

[29] Ungewitter EK, Yao HH. How to make a gonad: cellular mechanisms governing formation of the testes and ovaries. Sex Dev 2013; 7(1-3): 7-20.

[http://dx.doi.org/10.1159/000338612] [PMID: 22614391]

[30] Bartol FF, Wiley AA, Bagnell CA. Epigenetic programming of porcine endometrial function and the lactocrine hypothesis. Reprod Domest Anim 2008; 43(Suppl. 2): 273-9. [http://dx.doi.org/10.1111/j.1439-0531.2008.01174.x] [PMID: 18638135] 
[31] Luense LJ, Veiga-Lopez A, Padmanabhan V, Christenson LK. Developmental programming: gestational testosterone treatment alters fetal ovarian gene expression. Endocrinology 2011; 152(12): 4974-83. [http://dx.doi.org/10.1210/en.2011-1182] [PMID: 22009729]

[32] Gore AC, Walker DM, Zama AM, Armenti AE, Uzumcu M. Early life exposure to endocrine-disrupting chemicals causes lifelong molecular reprogramming of the hypothalamus and premature reproductive aging. Mol Endocrinol 2011; 25(12): 2157-68. [http://dx.doi.org/10.1210/me.2011-1210] [PMID: 22016562]

[33] Schwarz JM, Nugent BM, McCarthy MM. Developmental and hormone-induced epigenetic changes to estrogen and progesterone receptor genes in brain are dynamic across the life span. Endocrinology 2010; 151(10): 4871-81. [http://dx.doi.org/10.1210/en.2010-0142] [PMID: 20702577]

[34] Obata Y, Kono T. Maternal primary imprinting is established at a specific time for each gene throughout oocyte growth. J Biol Chem 2002; 277(7): 5285-9. [http://dx.doi.org/10.1074/jbc.M108586200] [PMID: 11713250]

[35] La Sala G, Farini D, De Felici M. Rapid estrogen signalling in mouse primordial germ cells. Exp Cell Res 2010; 316(10): 1716-27. [http://dx.doi.org/10.1016/j.yexcr.2010.03.024] [PMID: 20380832]

[36] Ge C, Yu M, Zhang C. G protein-coupled receptor 30 mediates estrogen-induced proliferation of primordial germ cells via EGFR/Akt/ßcatenin signaling pathway. Endocrinology 2012; 153(7): 3504-16. [http://dx.doi.org/10.1210/en.2012-1200] [PMID: 22635679]

[37] De Felici M. Nuclear reprogramming in mouse primordial germ cells: epigenetic contribution. Stem Cells Int 2011. 2011: 425863 [http://dx.doi.org/10.4061/2011/425863]

[38] Jefferson WN, Chevalier DM, Phelps JY, et al. Persistently altered epigenetic marks in the mouse uterus after neonatal estrogen exposure. Mol Endocrinol 2013; 27(10): 1666-77. [http://dx.doi.org/10.1210/me.2013-1211] [PMID: 24002655]

[39] Zhang Y, Fatima N, Dufau ML. Coordinated changes in DNA methylation and histone modifications regulate silencing/derepression of luteinizing hormone receptor gene transcription. Mol Cell Biol 2005; 25(18): 7929-39. [http://dx.doi.org/10.1128/MCB.25.18.7929-7939.2005] [PMID: 16135786]

[40] Monga R, Ghai S, Datta TK, Singh D. Tissue-specific promoter methylation and histone modification regulate CYP19 gene expression during folliculogenesis and luteinization in buffalo ovary. Gen Comp Endocrinol 2011; 173(1): 205-15. [http://dx.doi.org/10.1016/j.ygcen.2011.05.016] [PMID: 21663742]

[41] Meldi KM, Gaconnet GA, Mayo KE. DNA methylation and histone modifications are associated with repression of the inhibin $\alpha$ promoter in the rat corpus luteum. Endocrinology 2012; 153(10): 4905-17. [http://dx.doi.org/10.1210/en.2012-1292] [PMID: 22865368]

[42] LaSalle JM, Powell WT, Yasui DH. Epigenetic layers and players underlying neurodevelopment. Trends Neurosci 2013; 36(8): 460-70. [http://dx.doi.org/10.1016/j.tins.2013.05.001] [PMID: 23731492]

[43] Turner BM. Epigenetic responses to environmental change and their evolutionary implications. Philos Trans R Soc Lond B Biol Sci 2009; 364(1534): 3403-18.

[44] Sharma D, Blum J, Yang X, Beaulieu N, Macleod AR, Davidson NE. Release of methyl CpG binding proteins and histone deacetylase 1 from the Estrogen receptor alpha (ER) promoter upon reactivation in ER-negative human breast cancer cells. Mol Endocrinol 2005; 19(7): $1740-51$. [http://dx.doi.org/10.1210/me.2004-0011] [PMID: 15746193]

[45] Yoo CB, Jones PA. Epigenetic therapy of cancer: past, present and future. Nat Rev Drug Discov 2006; 5(1): 37-50. [http://dx.doi.org/10.1038/nrd1930] [PMID: 16485345]

[46] Bredfeldt TG, Greathouse KL, Safe SH, Hung MC, Bedford MT, Walker CL. Xenoestrogen-induced regulation of EZH2 and histone methylation via estrogen receptor signaling to PI3K/AKT. Mol Endocrinol 2010; 24(5): 993-1006. [http://dx.doi.org/10.1210/me.2009-0438] [PMID: 20351197]

[47] Sharma S, Kelly TK, Jones PA. Epigenetics in cancer. Carcinogenesis 2010; 31(1): 27-36. [http://dx.doi.org/10.1093/carcin/bgp220] [PMID: 19752007]

[48] Chen Y, Jefferson WN, Newbold RR, Padilla-Banks E, Pepling ME. Estradiol, progesterone, and genistein inhibit oocyte nest breakdown and primordial follicle assembly in the neonatal mouse ovary in vitro and in vivo. Endocrinology 2007; 148(8): 3580-90. [http://dx.doi.org/10.1210/en.2007-0088] [PMID: 17446182]

[49] Kezele P, Skinner MK. Regulation of ovarian primordial follicle assembly and development by estrogen and progesterone: endocrine model of follicle assembly. Endocrinology 2003; 144(8): 3329-37. [http://dx.doi.org/10.1210/en.2002-0131] [PMID: 12865310]

[50] Skinner MK. Regulation of primordial follicle assembly and development. Hum Reprod Update 2005; 11(5): 461-71. [http://dx.doi.org/10.1093/humupd/dmi020] [PMID: 16006439]

[51] Richards JS, Sharma SC, Falender AE, Lo YH. Expression of FKHR, FKHRL1, and AFX genes in the rodent ovary: evidence for regulation by IGF-I, estrogen, and the gonadotropins. Mol Endocrinol 2002; 16(3): 580-99. [http://dx.doi.org/10.1210/mend.16.3.0806] [PMID: 11875118] 
[52] van der Horst PH, Wang Y, van der Zee M, Burger CW, Blok LJ. Interaction between sex hormones and WNT/ $\beta$-catenin signal transduction in endometrial physiology and disease. Mol Cell Endocrinol 2012; 358(2): 176-84. [http://dx.doi.org/10.1016/j.mce.2011.06.010] [PMID: 21722706]

[53] Daftary GS, Taylor HS. Endocrine regulation of HOX genes. Endocr Rev 2006; 27(4): 331-55. [http://dx.doi.org/10.1210/er.2005-0018] [PMID: 16632680]

[54] Hewitt SC, O’Brien JE, Jameson JL, Kissling GE, Korach KS. Selective disruption of ERalpha DNA-binding activity alters uterine responsiveness to estradiol. Mol Endocrinol 2009; 23(12): 2111-6. [http://dx.doi.org/10.1210/me.2009-0356] [PMID: 19812388]

[55] Pepling ME, Spradling AC. Mouse ovarian germ cell cysts undergo programmed breakdown to form primordial follicles. Dev Biol 2001; 234(2): 339-51.

[http://dx.doi.org/10.1006/dbio.2001.0269] [PMID: 11397004]

[56] De Felici M, Lobascio AM, Klinger FG. Cell death in fetal oocytes: many players for multiple pathways. Autophagy 2008; 4(2): 240-2. [http://dx.doi.org/10.4161/auto.5410] [PMID: 18094606]

[57] Lobascio AM, Klinger FG, Scaldaferri ML, Farini D, De Felici M. Analysis of programmed cell death in mouse fetal oocytes. Reproduction 2007; 134(2): 241-52

[http://dx.doi.org/10.1530/REP-07-0141] [PMID: 17660234]

[58] Nilsson EE, Stanfield J, Skinner MK. Interactions between progesterone and tumor necrosis factor- $\alpha$ in the regulation of primordial follicle assembly. Reproduction 2006; 132(6): 877-86. [http://dx.doi.org/10.1530/REP-06-0045] [PMID: 17127748]

[59] Morrison LJ, Marcinkiewicz JL. Tumor necrosis factor alpha enhances oocyte/follicle apoptosis in the neonatal rat ovary. Biol Reprod 2002; 66(2): 450-7.

[http://dx.doi.org/10.1095/biolreprod66.2.450] [PMID: 11804962]

[60] Kim H, Nakajima T, Hayashi S, et al. Effects of diethylstilbestrol on programmed oocyte death and induction of polyovular follicles in neonatal mouse ovaries. Biol Reprod 2009; 81(5): 1002-9. [http://dx.doi.org/10.1095/biolreprod.108.070599] [PMID: 19553606]

[61] Bristol-Gould SK, Kreeger PK, Selkirk CG, et al. Postnatal regulation of germ cells by activin: the establishment of the initial follicle pool. Dev Biol 2006; 298(1): 132-48. [http://dx.doi.org/10.1016/j.ydbio.2006.06.025] [PMID: 16930587]

[62] Kipp JL, Kilen SM, Bristol-Gould S, Woodruff TK, Mayo KE. Neonatal exposure to estrogens suppresses activin expression and signaling in the mouse ovary. Endocrinology 2007; 148(5): 1968-76. [http://dx.doi.org/10.1210/en.2006-1083] [PMID: 17255206]

[63] Castrillon DH, Miao L, Kollipara R, Horner JW, DePinho RA. Suppression of ovarian follicle activation in mice by the transcription factor Foxo3a. Science 2003; 301(5630): 215-8. [http://dx.doi.org/10.1126/science.1086336] [PMID: 12855809]

[64] Yang JL, Zhang CP, Li L, et al. Testosterone induces redistribution of forkhead box-3a and down-regulation of growth and differentiation factor 9 messenger ribonucleic acid expression at early stage of mouse folliculogenesis. Endocrinology 2010; 151(2): 774-82. [http://dx.doi.org/10.1210/en.2009-0751] [PMID: 20032061]

[65] Zachow R, Uzumcu M. The hepatocyte growth factor system as a regulator of female and male gonadal function. J Endocrinol 2007; 195(3): 359-71.

[http://dx.doi.org/10.1677/JOE-07-0466] [PMID: 18000299]

[66] Mazerbourg S, Bondy CA, Zhou J, Monget P. The insulin-like growth factor system: a key determinant role in the growth and selection of ovarian follicles? a comparative species study. Reprod Domest Anim 2003; 38(4): 247-58. [http://dx.doi.org/10.1046/j.1439-0531.2003.00440.x] [PMID: 12887564]

[67] deMoura MD, Choi D, Adashi EY, Payne DW. Insulin-like growth factor-I-mediated amplification of follicle-stimulating hormone-supported progesterone accumulation by cultured rat granulosa cells: enhancement of steroidogenic enzyme activity and expression. Biol Reprod 1997; 56(4): 946-53.

[http://dx.doi.org/10.1095/biolreprod56.4.946] [PMID: 9096877]

[68] Ui M, Shimonaka M, Shimasaki S, Ling N. An insulin-like growth factor-binding protein in ovarian follicular fluid blocks follicle-stimulating hormone-stimulated steroid production by ovarian granulosa cells. Endocrinology 1989; 125(2): 912-6. [http://dx.doi.org/10.1210/endo-125-2-912] [PMID: 2473892]

[69] Cataldo NA, Woodruff TK, Giudice LC. Regulation of insulin-like growth factor binding protein production by human luteinizing granulosa cells cultured in defined medium. J Clin Endocrinol Metab 1993; 76(1): 207-15. [PMID: 7678423]

[70] Richards JS. Genetics of ovulation. Semin Reprod Med 2007; 25(4): 235-42. [http://dx.doi.org/10.1055/s-2007-980217] [PMID: 17594604]

[71] Henkes LE, Davis JS, Rueda BR. Mutant mouse models and their contribution to our knowledge of corpus luteum development, function and regression. Reprod Biol Endocrinol 2003; 1: 87. 
[http://dx.doi.org/10.1186/1477-7827-1-87] [PMID: 14613537]

[72] Stocco C, Telleria C, Gibori G. The molecular control of corpus luteum formation, function, and regression. Endocr Rev 2007; $28(1)$ : 117-49. [http://dx.doi.org/10.1210/er.2006-0022] [PMID: 17077191]

[73] Orvis GD, Behringer RR. Cellular mechanisms of Müllerian duct formation in the mouse. Dev Biol 2007; 306(2): 493-504. [http://dx.doi.org/10.1016/j.ydbio.2007.03.027] [PMID: 17467685]

[74] Kurita T. Normal and abnormal epithelial differentiation in the female reproductive tract. Differentiation 2011; 82(3): 117-26. [http://dx.doi.org/10.1016/j.diff.2011.04.008] [PMID: 21612855]

[75] Kurita T, Cooke PS, Cunha GR. Epithelial-stromal tissue interaction in paramesonephric (Müllerian) epithelial differentiation. Dev Biol 2001; 240(1): 194-211. [http://dx.doi.org/10.1006/dbio.2001.0458] [PMID: 11784056]

[76] Robboy SJ, Taguchi O, Cunha GR. Normal development of the human female reproductive tract and alterations resulting from experimental exposure to diethylstilbestrol. Hum Pathol 1982; 13(3): 190-8. [http://dx.doi.org/10.1016/S0046-8177(82)80177-9] [PMID: 7076207]

[77] Gray CA, Bartol FF, Tarleton BJ, et al. Developmental biology of uterine glands. Biol Reprod 2001; 65(5): 1311-23. [http://dx.doi.org/10.1095/biolreprod65.5.1311] [PMID: 11673245]

[78] Cooke PS, Spencer TE, Bartol FF, Hayashi K. Uterine glands: development, function and experimental model systems. Mol Hum Reprod 2013; 19(9): 547-58.

[http://dx.doi.org/10.1093/molehr/gat031] [PMID: 23619340]

[79] Spencer TE, Dunlap KA, Filant J. Comparative developmental biology of the uterus: insights into mechanisms and developmental disruption. Mol Cell Endocrinol 2012; 354(1-2): 34-53. [http://dx.doi.org/10.1016/j.mce.2011.09.035] [PMID: 22008458]

[80] Mericskay M, Kitajewski J, Sassoon D. Wnt5a is required for proper epithelial-mesenchymal interactions in the uterus. Development 2004; 131(9): 2061-72. [http://dx.doi.org/10.1242/dev.01090] [PMID: 15073149]

[81] Benson GV, Lim H, Paria BC, Satokata I, Dey SK, Maas RL. Mechanisms of reduced fertility in Hoxa-10 mutant mice: uterine homeosis and loss of maternal Hoxa-10 expression. Development 1996; 122(9): 2687-96. [PMID: 8787743]

[82] Branford WW, Benson GV, Ma L, Maas RL, Potter SS. Characterization of Hoxa-10/Hoxa-11 transheterozygotes reveals functional redundancy and regulatory interactions. Dev Biol 2000; 224(2): 373-87. [http://dx.doi.org/10.1006/dbio.2000.9809] [PMID: 10926774]

[83] Baker J, Hardy MP, Zhou J, et al. Effects of an Igf1 gene null mutation on mouse reproduction. Mol Endocrinol 1996; 10(7): 903-18. [PMID: 8813730]

[84] Cooke PS, Buchanan DL, Lubahn DB, Cunha GR. Mechanism of estrogen action: lessons from the estrogen receptor- $\alpha$ knockout mouse. Biol Reprod 1998; 59(3): 470-5. [http://dx.doi.org/10.1095/biolreprod59.3.470] [PMID: 9716542]

[85] Carpenter KD, Hayashi K, Spencer TE. Ovarian regulation of endometrial gland morphogenesis and activin-follistatin system in the neonatal ovine uterus. Biol Reprod 2003; 69(3): 851-60.

[http://dx.doi.org/10.1095/biolreprod.103.016337] [PMID: 12748121]

[86] Albrecht ED, Pepe GJ. Estrogen regulation of placental angiogenesis and fetal ovarian development during primate pregnancy. Int J Dev Biol 2010; 54(2-3): 397-408. [http://dx.doi.org/10.1387/ijdb.082758ea] [PMID: 19876841]

[87] Nilsson EE, Skinner MK. Progesterone regulation of primordial follicle assembly in bovine fetal ovaries. Mol Cell Endocrinol 2009; 313(1-2): 9-16. [http://dx.doi.org/10.1016/j.mce.2009.09.004] [PMID: 19747959]

[88] Sar M, Welsch F. Differential expression of estrogen receptor- $\beta$ and estrogen receptor- $\alpha$ in the rat ovary. Endocrinology 1999; 140(2): $963-71$. [PMID: 9927330]

[89] Chen Y, Breen K, Pepling ME. Estrogen can signal through multiple pathways to regulate oocyte cyst breakdown and primordial follicle assembly in the neonatal mouse ovary. J Endocrinol 2009; 202(3): 407-17. [http://dx.doi.org/10.1677/JOE-09-0109] [PMID: 19505948]

[90] Couse JF, Korach KS. Estrogen receptor null mice: what have we learned and where will they lead us? Endocr Rev 1999; 20(3): 358-417. [http://dx.doi.org/10.1210/edrv.20.3.0370] [PMID: 10368776]

[91] Couse JF, Yates MM, Deroo BJ, Korach KS. Estrogen receptor- $\beta$ is critical to granulosa cell differentiation and the ovulatory response to gonadotropins. Endocrinology 2005; 146(8): 3247-62. [http://dx.doi.org/10.1210/en.2005-0213] [PMID: 15831568]

[92] Emmen JM, Couse JF, Elmore SA, Yates MM, Kissling GE, Korach KS. In vitro growth and ovulation of follicles from ovaries of estrogen receptor (ER) $\alpha$ and ER $\beta$ null mice indicate a role for ER $\beta$ in follicular maturation. Endocrinology 2005; 146(6): 2817-26. [http://dx.doi.org/10.1210/en.2004-1108] [PMID: 15731357] 
[93] Drummond AE, Fuller PJ. The importance of ER $\beta$ signalling in the ovary. J Endocrinol 2010; 205(1): 15-23. [http://dx.doi.org/10.1677/JOE-09-0379] [PMID: 20019181]

[94] Kuiper GG, Lemmen JG, Carlsson B, et al. Interaction of estrogenic chemicals and phytoestrogens with estrogen receptor $\beta$. Endocrinology 1998; 139(10): 4252-63.

[PMID: 9751507]

[95] Jefferson W, Newbold R, Padilla-Banks E, Pepling M. Neonatal genistein treatment alters ovarian differentiation in the mouse: inhibition of oocyte nest breakdown and increased oocyte survival. Biol Reprod 2006; 74(1): 161-8. [http://dx.doi.org/10.1095/biolreprod.105.045724] [PMID: 16192398]

[96] Jefferson WN, Couse JF, Padilla-Banks E, Korach KS, Newbold RR. Neonatal exposure to genistein induces estrogen receptor (ER) $\alpha$ expression and multioocyte follicles in the maturing mouse ovary: evidence for ER $\beta$-mediated and nonestrogenic actions. Biol Reprod 2002; 67(4): 1285-96.

[http://dx.doi.org/10.1095/biolreprod67.4.1285] [PMID: 12297547]

[97] Kirigaya A, Kim H, Hayashi S, et al. Involvement of estrogen receptor beta in the induction of polyovular follicles in mouse ovaries exposed neonatally to diethylstilbestrol. Zoolog Sci 2009; 26(10): 704-12. [http://dx.doi.org/10.2108/zsj.26.704] [PMID: 19832683]

[98] Woodruff TK, Mayo KE. To $\beta$ or not to beta: estrogen receptors and ovarian function. Endocrinology 2005; 146(8): 3244-6. [http://dx.doi.org/10.1210/en.2005-0630] [PMID: 16009972]

[99] Couse JF, Bunch DO, Lindzey J, Schomberg DW, Korach KS. Prevention of the polycystic ovarian phenotype and characterization of ovulatory capacity in the estrogen receptor- $\alpha$ knockout mouse. Endocrinology 1999; 140(12): 5855-65. [PMID: 10579351]

[100] Pedram A, Razandi M, Kim JK, et al. Developmental phenotype of a membrane only estrogen receptor $\alpha$ (MOER) mouse. J Biol Chem 2009; 284(6): 3488-95. [http://dx.doi.org/10.1074/jbc.M806249200] [PMID: 19054762]

[101] Korach KS, Horigome T, Tomooka Y, Yamashita S, Newbold RR, McLachlan JA. Immunodetection of estrogen receptor in epithelial and stromal tissues of neonatal mouse uterus. Proc Natl Acad Sci USA 1988; 85(10): 3334-7. [http://dx.doi.org/10.1073/pnas.85.10.3334] [PMID: 3368444]

[102] Okada A, Ohta Y, Buchanan DL, et al. Changes in ontogenetic expression of estrogen receptor $\alpha$ and not of estrogen receptor $\beta$ in the female rat reproductive tract. J Mol Endocrinol 2002; 28(2): 87-97. [http://dx.doi.org/10.1677/jme.0.0280087] [PMID: 11932206]

[103] Smith OW, Gabbe SG. Diethylstilbestrol in the prevention and treatment of complications of pregnancy. 1948. Am J Obstet Gynecol 1999; 181(6): 1570-1. [http://dx.doi.org/10.1016/S0002-9378(99)70409-6] [PMID: 10601944]

[104] Newbold RR. Lessons learned from perinatal exposure to diethylstilbestrol. Toxicol Appl Pharmacol 2004; $199(2): 142-50$. [http://dx.doi.org/10.1016/j.taap.2003.11.033] [PMID: 15313586]

[105] Blatt J, Van Le L, Weiner T, Sailer S. Ovarian carcinoma in an adolescent with transgenerational exposure to diethylstilbestrol. J Pediatr Hematol Oncol 2003; 25(8): 635-6. [http://dx.doi.org/10.1097/00043426-200308000-00009] [PMID: 12902917]

[106] Titus-Ernstoff L, Troisi R, Hatch EE, et al. Menstrual and reproductive characteristics of women whose mothers were exposed in utero to diethylstilbestrol (DES). Int J Epidemiol 2006; 35(4): 862-8. [http://dx.doi.org/10.1093/ije/dyl106] [PMID: 16723367]

[107] Palmlund I. Exposure to a xenoestrogen before birth: the diethylstilbestrol experience. J Psychosom Obstet Gynaecol 1996; 17(2): 71-84. [http://dx.doi.org/10.3109/01674829609025667] [PMID: 8819018]

[108] Goldberg JM, Falcone T. Effect of diethylstilbestrol on reproductive function. Fertil Steril 1999; 72(1): 1-7. [http://dx.doi.org/10.1016/S0015-0282(99)00153-3] [PMID: 10428139]

[109] Turusov VS, Trukhanova LS, Parfenov YuD, Tomatis L. Occurrence of tumours in the descendants of CBA male mice prenatally treated with diethylstilbestrol. Int J Cancer 1992; 50(1): 131-5. [http://dx.doi.org/10.1002/ijc.2910500126] [PMID: 1728603]

[110] Newbold RR, Hanson RB, Jefferson WN, Bullock BC, Haseman J, McLachlan JA. Proliferative lesions and reproductive tract tumors in male descendants of mice exposed developmentally to diethylstilbestrol. Carcinogenesis 2000; 21(7): 1355-63. [http://dx.doi.org/10.1093/carcin/21.7.1355] [PMID: 10874014]

[111] Newbold RR, Hanson RB, Jefferson WN, Bullock BC, Haseman J, McLachlan JA. Increased tumors but uncompromised fertility in the female descendants of mice exposed developmentally to diethylstilbestrol. Carcinogenesis 1998; 19(9): 1655-63. [http://dx.doi.org/10.1093/carcin/19.9.1655] [PMID: 9771938]

[112] Walker BE, Haven MI. Intensity of multigenerational carcinogenesis from diethylstilbestrol in mice. Carcinogenesis 1997; 18(4): 791-3. [http://dx.doi.org/10.1093/carcin/18.4.791] [PMID: 9111216]

[113] Wordinger RJ, Highman B. Histology and ultrastructure of the adult mouse ovary following a single prenatal exposure to diethylstilbestrol. Virchows Arch B Cell Pathol Incl Mol Pathol 1984; 45(3): 241-53. 
[http://dx.doi.org/10.1007/BF02889867] [PMID: 6146217]

[114] Haney AF, Newbold RR, McLachlan JA. Prenatal diethylstilbestrol exposure in the mouse: effects on ovarian histology and steroidogenesis in vitro. Biol Reprod 1984; 30(2): 471-8.

[http://dx.doi.org/10.1095/biolreprod30.2.471] [PMID: 6704476]

[115] Tenenbaum A, Forsberg JG. Structural and functional changes in ovaries from adult mice treated with diethylstilboestrol in the neonatal period. J Reprod Fertil 1985; 73(2): 465-77.

[http://dx.doi.org/10.1530/jrf.0.0730465] [PMID: 4039364]

[116] McLachlan JA, Newbold RR, Shah HC, Hogan MD, Dixon RL. Reduced fertility in female mice exposed transplacentally to diethylstilbestrol (DES). Fertil Steril 1982; 38(3): 364-71. [PMID: 7117561]

[117] Wordinger RJ, Derrenbacker J. In utero exposure of mice to diethylstilbestrol alters neonatal ovarian follicle growth and development. Acta Anat (Basel) 1989; 134(4): 312-8.

[http://dx.doi.org/10.1159/000146708] [PMID: 2741660]

[118] Halling A, Forsberg JG. Effects of neonatal exposure to diethylstilbestrol on early mouse embryo development in vivo and in vitro. Biol Reprod 1991; 45(1): 157-62. [http://dx.doi.org/10.1095/biolreprod45.1.157] [PMID: 1878430]

[119] Iguchi T, Kamiya K, Uesugi Y, Sayama K, Takasugi N. In vitro fertilization of oocytes from polyovular follicles in mouse ovaries exposed neonatally to diethylstilbestrol. In Vivo 1991; 5(4): 359-63. [PMID: 1810421]

[120] Forsberg JG, Halling A. Failure to detect a second-generation effect in female mice after neonatal treatment with an estrogen (diethylstilbestrol). Acta Anat (Basel) 1992; 144(2): 103-6.

[http://dx.doi.org/10.1159/000147292] [PMID: 1514366]

[121] Iguchi T, Takasugi N. Polyovular follicles in the ovary of immature mice exposed prenatally to diethylstilbestrol. Anat Embryol (Berl) 1986; 175(1): 53-5. [http://dx.doi.org/10.1007/BF00315455] [PMID: 3799991]

[122] Iguchi T, Fukazawa Y, Uesugi Y, Takasugi N. Polyovular follicles in mouse ovaries exposed neonatally to diethylstilbestrol in vivo and in vitro. Biol Reprod 1990; 43(3): 478-84.

[http://dx.doi.org/10.1095/biolreprod43.3.478] [PMID: 2271729]

[123] Herbst AL, Ulfelder H, Poskanzer DC. Adenocarcinoma of the vagina. Association of maternal stilbestrol therapy with tumor appearance in young women. N Engl J Med 1971; 284(15): 878-81.

[http://dx.doi.org/10.1056/NEJM197104222841604] [PMID: 5549830]

[124] Kitajewski J, Sassoon D. The emergence of molecular gynecology: homeobox and Wnt genes in the female reproductive tract. BioEssays 2000; 22(10): 902-10. [http://dx.doi.org/10.1002/1521-1878(200010)22:10<902::AID-BIES5>3.0.CO;2-\#] [PMID: 10984716]

[125] McLachlan JA, Newbold RR, Bullock BC. Long-term effects on the female mouse genital tract associated with prenatal exposure to diethylstilbestrol. Cancer Res 1980; 40(11): 3988-99.

[PMID: 7193511]

[126] Nelson KG, Sakai Y, Eitzman B, Steed T, McLachlan J. Exposure to diethylstilbestrol during a critical developmental period of the mouse reproductive tract leads to persistent induction of two estrogen-regulated genes. Cell Growth Differ 1994; 5(6): 595-606. [PMID: 8086337]

[127] Lingham RB, Stancel GM, Loose-Mitchell DS. Estrogen regulation of epidermal growth factor receptor messenger ribonucleic acid. Mol Endocrinol 1988; 2(3): 230-5. [http://dx.doi.org/10.1210/mend-2-3-230] [PMID: 3398852]

[128] Loose-Mitchell DS, Chiappetta C, Stancel GM. Estrogen regulation of c-fos messenger ribonucleic acid. Mol Endocrinol 1988; 2(10): 946-51. [http://dx.doi.org/10.1210/mend-2-10-946] [PMID: 3141795]

[129] Kamiya K, Sato T, Nishimura N, Goto Y, Kano K, Iguchi T. Expression of estrogen receptor and proto-oncogene messenger ribonucleic acids in reproductive tracts of neonatally diethylstilbestrol-exposed female mice with or without post-puberal estrogen administration. Exp Clin Endocrinol Diabetes 1996; 104(2): 111-22. [http://dx.doi.org/10.1055/s-0029-1211432] [PMID: 8740934]

[130] Falck L, Forsberg JG. Immunohistochemical studies on the expression and estrogen dependency of EGF and its receptor and C-fos protooncogene in the uterus and vagina of normal and neonatally estrogen-treated mice. Anat Rec 1996; 245(3): 459-71. [http://dx.doi.org/10.1002/(SICI)1097-0185(199607)245:3<459::AID-AR2>3.0.CO;2-N] [PMID: 8800404]

[131] Ma L, Benson GV, Lim H, Dey SK, Maas RL. Abdominal B (AbdB) Hoxa genes: regulation in adult uterus by estrogen and progesterone and repression in müllerian duct by the synthetic estrogen diethylstilbestrol (DES). Dev Biol 1998; 197(2): 141-54. [http://dx.doi.org/10.1006/dbio.1998.8907] [PMID: 9630742]

[132] Block K, Kardana A, Igarashi P, Taylor HS. In utero diethylstilbestrol (DES) exposure alters Hox gene expression in the developing müllerian system. FASEB J 2000; 14(9): 1101-8. [PMID: 10834931] 
[133] Miller C, Degenhardt K, Sassoon DA. Fetal exposure to DES results in de-regulation of Wnt7a during uterine morphogenesis. Nat Genet 1998; 20(3): 228-30. [http://dx.doi.org/10.1038/3027] [PMID: 9806537]

[134] Huang WW, Yin Y, Bi Q, et al. Developmental diethylstilbestrol exposure alters genetic pathways of uterine cytodifferentiation. Mol Endocrinol 2005; 19(3): 669-82. [http://dx.doi.org/10.1210/me.2004-0155] [PMID: 15591538]

[135] Yin Y, Lin C, Ma L. MSX2 promotes vaginal epithelial differentiation and wolffian duct regression and dampens the vaginal response to diethylstilbestrol. Mol Endocrinol 2006; 20(7): 1535-46. [http://dx.doi.org/10.1210/me.2005-0451] [PMID: 16513791]

[136] Newbold RR, Bullock BC, McLachlan JA. Uterine adenocarcinoma in mice following developmental treatment with estrogens: a model for hormonal carcinogenesis. Cancer Res 1990; 50(23): 7677-81. [PMID: 2174729]

[137] Li S, Washburn KA, Moore R, et al. Developmental exposure to diethylstilbestrol elicits demethylation of estrogen-responsive lactoferrin gene in mouse uterus. Cancer Res 1997; 57(19): 4356-9. [PMID: 9331098]

[138] Li S, Hansman R, Newbold R, Davis B, McLachlan JA, Barrett JC. Neonatal diethylstilbestrol exposure induces persistent elevation of c-fos expression and hypomethylation in its exon-4 in mouse uterus. Mol Carcinog 2003; 38(2): 78-84. [http://dx.doi.org/10.1002/mc.10147] [PMID: 14502647]

[139] Sato K, Fukata H, Kogo Y, Ohgane J, Shiota K, Mori C. Neonatal exposure to diethylstilbestrol alters expression of DNA methyltransferases and methylation of genomic DNA in the mouse uterus. Endocr J 2009; 56(1): 131-9. [http://dx.doi.org/10.1507/endocrj.K08E-239] [PMID: 18997445]

[140] Li S, Chiang TC, Richard-Davis G, Barrett JC, Mclachlan JA. DNA hypomethylation and imbalanced expression of DNA methyltransferases (DNMT1, 3A, and 3B) in human uterine leiomyoma. Gynecol Oncol 2003; 90(1): 123-30. [http://dx.doi.org/10.1016/S0090-8258(03)00194-X] [PMID: 12821352]

[141] Bromer JG, Wu J, Zhou Y, Taylor HS. Hypermethylation of homeobox A10 by in utero diethylstilbestrol exposure: an epigenetic mechanism for altered developmental programming. Endocrinology 2009; 150(7): 3376-82. [http://dx.doi.org/10.1210/en.2009-0071] [PMID: 19299448]

[142] Greathouse KL, Bredfeldt T, Everitt JI, et al. Environmental estrogens differentially engage the histone methyltransferase EZH2 to increase risk of uterine tumorigenesis. Mol Cancer Res 2012; 10(4): 546-57. [http://dx.doi.org/10.1158/1541-7786.MCR-11-0605] [PMID: 22504913]

[143] Cummings AM. Methoxychlor as a model for environmental estrogens. Crit Rev Toxicol 1997; 27(4): $367-79$. [http://dx.doi.org/10.3109/10408449709089899] [PMID: 9263644]

[144] Gaido KW, Maness SC, McDonnell DP, Dehal SS, Kupfer D, Safe S. Interaction of methoxychlor and related compounds with estrogen receptor $\alpha$ and $\beta$, and androgen receptor: structure-activity studies. Mol Pharmacol 2000; 58(4): 852-8. [PMID: 10999957]

[145] Uzumcu M, Zachow R. Developmental exposure to environmental endocrine disruptors: consequences within the ovary and on female reproductive function. Reprod Toxicol 2007; 23(3): 337-52. [http://dx.doi.org/10.1016/j.reprotox.2006.10.006] [PMID: 17140764]

[146] Axmon A, Rylander L, Strömberg U, Hagmar L. Miscarriages and still births in women with a high intake of fish contaminated with persistent organochlorine compounds. Int Arch Occup Environ Health 2000; 73(3): 204-8. [http://dx.doi.org/10.1007/s004200050028] [PMID: 10787136]

[147] Cohn BA, Cirillo PM, Wolff MS, et al. DDT and DDE exposure in mothers and time to pregnancy in daughters. Lancet 2003; 361(9376): 2205-6.

[http://dx.doi.org/10.1016/S0140-6736(03)13776-2] [PMID: 12842376]

[148] Bretveld RW, Hooiveld M, Zielhuis GA, Pellegrino A, van Rooij IA, Roeleveld N. Reproductive disorders among male and female greenhouse workers. Reprod Toxicol 2008; 25(1): 107-14. [http://dx.doi.org/10.1016/j.reprotox.2007.08.005] [PMID: 17964116]

[149] Fuortes L, Clark MK, Kirchner HL, Smith EM. Association between female infertility and agricultural work history. Am J Ind Med 1997; 31(4): 445-51. [http://dx.doi.org/10.1002/(SICI)1097-0274(199704)31:4<445::AID-AJIM11>3.0.CO;2-\#] [PMID: 9093660]

[150] Harris SJ, Cecil HC, Bitman J. Effect of several dietary levels of technical methoxychlor on reproduction in rats. J Agric Food Chem 1974; 22(6): 969-73.

[http://dx.doi.org/10.1021/jf60196a018] [PMID: 4430807]

[151] Martinez EM, Swartz WJ. Effects of methoxychlor on the reproductive system of the adult female mouse. 1. Gross and histologic observations. Reprod Toxicol 1991; 5(2): 139-47. [http://dx.doi.org/10.1016/0890-6238(91)90042-E] [PMID: 1807545]

[152] Hall DL, Payne LA, Putnam JM, Huet-Hudson YM. Effect of methoxychlor on implantation and embryo development in the mouse. Reprod 
Toxicol 1997; 11(5): 703-8.

[http://dx.doi.org/10.1016/S0890-6238(97)00026-9] [PMID: 9311579]

[153] Cummings AM, Gray LE Jr. Antifertility effect of methoxychlor in female rats: dose and time-dependent blockade of pregnancy. Toxicol Appl Pharmacol 1989; 97(3): 454-62. [http://dx.doi.org/10.1016/0041-008X(89)90250-0] [PMID: 2609343]

[154] Bal HS. Effect of methoxychlor on reproductive systems of the rat. Proc Soc Exp Biol Med 1984; 176(2): 187-96. [http://dx.doi.org/10.3181/00379727-176-41861] [PMID: 6718363]

[155] Okazaki K, Okazaki S, Nishimura S, et al. A repeated 28-day oral dose toxicity study of methoxychlor in rats, based on the 'enhanced OECD test guideline 407' for screening endocrine-disrupting chemicals. Arch Toxicol 2001; 75(9): 513-21. [http://dx.doi.org/10.1007/s002040100273] [PMID: 11760811]

[156] Borgeest C, Symonds D, Mayer LP, Hoyer PB, Flaws JA. Methoxychlor may cause ovarian follicular atresia and proliferation of the ovarian epithelium in the mouse. Toxicol Sci 2002; 68(2): 473-8. [http://dx.doi.org/10.1093/toxsci/68.2.473] [PMID: 12151644]

[157] Gray LE Jr, Ostby J, Ferrell J, et al. A dose-response analysis of methoxychlor-induced alterations of reproductive development and function in the rat. Fundam Appl Toxicol 1989; 12(1): 92-108. [http://dx.doi.org/10.1016/0272-0590(89)90065-1] [PMID: 2925022]

[158] Chapin RE, Harris MW, Davis BJ, et al. The effects of perinatal/juvenile methoxychlor exposure on adult rat nervous, immune, and reproductive system function. Fundam Appl Toxicol 1997; 40(1): 138-57. [http://dx.doi.org/10.1006/faat.1997.2381] [PMID: 9398496]

[159] You L, Casanova M, Bartolucci EJ, et al. Combined effects of dietary phytoestrogen and synthetic endocrine-active compound on reproductive development in Sprague-Dawley rats: genistein and methoxychlor. Toxicol Sci 2002; 66(1): 91-104. [http://dx.doi.org/10.1093/toxsci/66.1.91] [PMID: 11861976]

[160] Armenti AE, Zama AM, Passantino L, Uzumcu M. Developmental methoxychlor exposure affects multiple reproductive parameters and ovarian folliculogenesis and gene expression in adult rats. Toxicol Appl Pharmacol 2008; 233(2): 286-96. [http://dx.doi.org/10.1016/j.taap.2008.09.010] [PMID: 18848953]

[161] Tang WY, Newbold R, Mardilovich K, et al. Persistent hypomethylation in the promoter of nucleosomal binding protein 1 (Nsbp1) correlates with overexpression of Nsbp1 in mouse uteri neonatally exposed to diethylstilbestrol or genistein. Endocrinology 2008; 149(12): 5922-31. [http://dx.doi.org/10.1210/en.2008-0682] [PMID: 18669593]

[162] Tullner WW. Uterotrophic action of the insecticide methoxychlor. Science 1961; 133(3453): 647. [http://dx.doi.org/10.1126/science.133.3453.647] [PMID: 13778585]

[163] Walters LM, Rourke AW, Eroschenko VP. Purified methoxychlor stimulates the reproductive tract in immature female mice. Reprod Toxicol 1993; 7(6): 599-606.

[http://dx.doi.org/10.1016/0890-6238(93)90036-7] [PMID: 8118110]

[164] Rourke AW, Eroschenko VP, Washburn LJ. Protein secretions in mouse uterus after methoxychlor or estradiol exposure. Reprod Toxicol 1991; 5(5): 437-42. [http://dx.doi.org/10.1016/0890-6238(91)90007-3] [PMID: 1806153]

[165] Gray LE Jr, Ostby JS, Ferrell JM, Sigmon ER, Goldman JM. Methoxychlor induces estrogen-like alterations of behavior and the reproductive tract in the female rat and hamster: effects on sex behavior, running wheel activity, and uterine morphology. Toxicol Appl Pharmacol 1988; 96(3): 525-40.

[http://dx.doi.org/10.1016/0041-008X(88)90012-9] [PMID: 3206530]

[166] Eroschenko VP, Rourke AW, Sims WF. Estradiol or methoxychlor stimulates estrogen receptor (ER) expression in uteri. Reprod Toxicol 1996; 10(4): 265-71. [http://dx.doi.org/10.1016/0890-6238(96)00055-X] [PMID: 8829249]

[167] Metcalf JL, Laws SC, Cummings AM. Methoxychlor mimics the action of $17 \beta$-estradiol on induction of uterine epidermal growth factor receptors in immature female rats. Reprod Toxicol 1996; 10(5): 393-9. [http://dx.doi.org/10.1016/0890-6238(96)00085-8] [PMID: 8888411]

[168] Cummings AM, Gray LE Jr. Methoxychlor affects the decidual cell response of the uterus but not other progestational parameters in female rats. Toxicol Appl Pharmacol 1987; 90(2): 330-6. [http://dx.doi.org/10.1016/0041-008X(87)90340-1] [PMID: 3629607]

[169] Uzumcu M, Kuhn PE, Marano JE, Armenti AE, Passantino L. Early postnatal methoxychlor exposure inhibits folliculogenesis and stimulates anti-Mullerian hormone production in the rat ovary. J Endocrinol 2006; 191(3): 549-58. [http://dx.doi.org/10.1677/joe.1.06592] [PMID: 17170213]

[170] Ingermann RL, Bencic DC, Eroschenko VP. Methoxychlor effects on hatching and larval startle response in the salamander Ambystoma macrodactylum are independent of its estrogenic actions. Bull Environ Contam Toxicol 1999; 62(5): 578-83. [http://dx.doi.org/10.1007/s001289900914] [PMID: 10227837]

[171] Mwatibo JM, Green JD. Estradiol disrupts sea urchin embryogenesis differently from methoxychlor. Bull Environ Contam Toxicol 1998; 61(5): 577-82. [http://dx.doi.org/10.1007/PL00002974] [PMID: 9841716] 
[172] Fei X, Chung H, Taylor HS. Methoxychlor disrupts uterine Hoxa10 gene expression. Endocrinology 2005; $146(8): 3445-51$. [http://dx.doi.org/10.1210/en.2005-0341] [PMID: 15890768]

[173] Bennetts HW, Underwood EJ. The oestrogenic effects of subterranean clover (trifolium subterraneum); uterine maintenance in the ovariectomised ewe on clover grazing. Aust J Exp Biol Med Sci 1951; 29(4): 249-53. [http://dx.doi.org/10.1038/icb.1951.29] [PMID: 14886261]

[174] Setchell KD, Zimmer-Nechemias L, Cai J, Heubi JE. Isoflavone content of infant formulas and the metabolic fate of these phytoestrogens in early life. Am J Clin Nutr 1998; 68(6 Suppl.): 1453-1461S. [PMID: 9848516]

[175] Johns P, Dowlati L, Wargo W. Determination of isoflavones in ready-to-feed soy-based infant formula. J AOAC Int 2003; 86(1): 72-8 [PMID: 12607743]

[176] D'Aloisio AA, Baird DD, DeRoo LA, Sandler DP. Association of intrauterine and early-life exposures with diagnosis of uterine leiomyomata by 35 years of age in the Sister Study. Environ Health Perspect 2010; 118(3): 375-81. [http://dx.doi.org/10.1289/ehp.0901423] [PMID: 20194067]

[177] Jefferson WN, Patisaul HB, Williams CJ. Reproductive consequences of developmental phytoestrogen exposure. Reproduction 2012; 143(3): 247-60. [http://dx.doi.org/10.1530/REP-11-0369] [PMID: 22223686]

[178] Jefferson WN, Padilla-Banks E, Newbold RR. Adverse effects on female development and reproduction in CD-1 mice following neonatal exposure to the phytoestrogen genistein at environmentally relevant doses. Biol Reprod 2005; 73(4): 798-806. [http://dx.doi.org/10.1095/biolreprod.105.041277] [PMID: 15930323]

[179] Jefferson WN. Neonatal exposure to the endocrine disruptor genistein adversely affects fertilization rate and oocyte qualit In: Endocrine Society's 88 ${ }^{\text {th }}$ Annual Meeting; Boston, MA. 2006.

[180] Nagao T, Yoshimura S, Saito Y, Nakagomi M, Usumi K, Ono H. Reproductive effects in male and female rats of neonatal exposure to genistein. Reprod Toxicol 2001; 15(4): 399-411. [http://dx.doi.org/10.1016/S0890-6238(01)00141-1] [PMID: 11489596]

[181] Todaka E, Sakurai K, Fukata H, et al. Fetal exposure to phytoestrogens-the difference in phytoestrogen status between mother and fetus. Environ Res 2005; 99(2): 195-203.

[http://dx.doi.org/10.1016/j.envres.2004.11.006] [PMID: 16194669]

[182] Nikaido Y, Yoshizawa K, Danbara N, et al. Effects of maternal xenoestrogen exposure on development of the reproductive tract and mammary gland in female CD-1 mouse offspring. Reprod Toxicol 2004; 18(6): 803-11. [http://dx.doi.org/10.1016/j.reprotox.2004.05.002] [PMID: 15279878]

[183] Jefferson WN, Doerge D, Padilla-Banks E, Woodling KA, Kissling GE, Newbold R. Oral exposure to genistin, the glycosylated form of genistein, during neonatal life adversely affects the female reproductive system. Environ Health Perspect 2009; 117(12): 1883-9. [http://dx.doi.org/10.1289/ehp.0900923] [PMID: 20049207]

[184] Patisaul HB, Adewale HB. Long-term effects of environmental endocrine disruptors on reproductive physiology and behavior. Front Behav Neurosci 2009; 3: 10.

[http://dx.doi.org/10.3389/neuro.08.010.2009] [PMID: 19587848]

[185] Jefferson WN, Padilla-Banks E, Clark G, Newbold RR. Assessing estrogenic activity of phytochemicals using transcriptional activation and immature mouse uterotrophic responses. J Chromatogr B Analyt Technol Biomed Life Sci 2002; 777(1-2): 179-89. [http://dx.doi.org/10.1016/S1570-0232(02)00493-2] [PMID: 12270211]

[186] Jefferson WN, Padilla-Banks E, Newbold RR. Disruption of the developing female reproductive system by phytoestrogens: genistein as an example. Mol Nutr Food Res 2007; 51(7): 832-44. [http://dx.doi.org/10.1002/mnfr.200600258] [PMID: 17604387]

[187] Strom BL, Schinnar R, Ziegler EE, et al. Exposure to soy-based formula in infancy and endocrinological and reproductive outcomes in young adulthood. JAMA 2001; 286(7): 807-14. [http://dx.doi.org/10.1001/jama.286.7.807] [PMID: 11497534]

[188] Jefferson WN, Padilla-Banks E, Goulding EH, Lao SP, Newbold RR, Williams CJ. Neonatal exposure to genistein disrupts ability of female mouse reproductive tract to support preimplantation embryo development and implantation. Biol Reprod 2009; 80(3): 425-31. [http://dx.doi.org/10.1095/biolreprod.108.073171] [PMID: 19005167]

[189] Chinigarzadeh A, Kassim NM, Muniandy S, Salleh N. Genistein-induced fluid accumulation in ovariectomised rats' uteri is associated with increased cystic fibrosis transmembrane regulator expression. Clinics (Sao Paulo) 2014; 69(2): 111-9. [http://dx.doi.org/10.6061/clinics/2014(02)07] [PMID: 24519202]

[190] Vandenberg LN, Maffini MV, Sonnenschein C, Rubin BS, Soto AM. Bisphenol-A and the great divide: a review of controversies in the field of endocrine disruption. Endocr Rev 2009; 30(1): 75-95. [http://dx.doi.org/10.1210/er.2008-0021] [PMID: 19074586]

[191] Zama AM, Uzumcu M. Epigenetic effects of endocrine-disrupting chemicals on female reproduction: an ovarian perspective. Front Neuroendocrinol 2010; 31(4): 420-39. [http://dx.doi.org/10.1016/j.yfrne.2010.06.003] [PMID: 20609371] 
[192] Rochester JR. Bisphenol A and human health: a review of the literature. Reprod Toxicol 2013; $42: 132-55$. [http://dx.doi.org/10.1016/j.reprotox.2013.08.008] [PMID: 23994667]

[193] Calafat AM, Ye X, Wong LY, Reidy JA, Needham LL. Exposure of the U.S. population to bisphenol A and 4-tertiary-octylphenol: 2003-2004. Environ Health Perspect 2008; 116(1): 39-44. [http://dx.doi.org/10.1289/ehp.10753] [PMID: 18197297]

[194] Brede C, Fjeldal P, Skjevrak I, Herikstad H. Increased migration levels of bisphenol A from polycarbonate baby bottles after dishwashing, boiling and brushing. Food Addit Contam 2003; 20(7): 684-9. [http://dx.doi.org/10.1080/0265203031000119061] [PMID: 12888395]

[195] Calafat AM, Weuve J, Ye X, et al. Exposure to bisphenol A and other phenols in neonatal intensive care unit premature infants. Environ Health Perspect 2009; 117(4): 639-44. [http://dx.doi.org/10.1289/ehp.0800265] [PMID: 19440505]

[196] Carwile JL, Luu HT, Bassett LS, et al. Polycarbonate bottle use and urinary bisphenol A concentrations. Environ Health Perspect 2009; 117(9): 1368-72. [http://dx.doi.org/10.1289/ehp.0900604] [PMID: 19750099]

[197] Mok-Lin E, Ehrlich S, Williams PL, et al. Urinary bisphenol A concentrations and ovarian response among women undergoing IVF. Int J Androl 2010; 33(2): 385-93. [http://dx.doi.org/10.1111/j.1365-2605.2009.01014.x] [PMID: 20002217]

[198] Fujimoto VY, Kim D, vom Saal FS, Lamb JD, Taylor JA, Bloom MS. Serum unconjugated bisphenol A concentrations in women may adversely influence oocyte quality during in vitro fertilization. Fertil Steril 2011; 95(5): 1816-9. [http://dx.doi.org/10.1016/j.fertnstert.2010.11.008] [PMID: 21122836]

[199] vom Saal FS, Akingbemi BT, Belcher SM, et al. Chapel Hill bisphenol A expert panel consensus statement: integration of mechanisms, effects in animals and potential to impact human health at current levels of exposure. Reprod Toxicol 2007; 24(2): 131-8. [http://dx.doi.org/10.1016/j.reprotox.2007.07.005] [PMID: 17768031]

[200] Gould JC, Leonard LS, Maness SC, et al. Bisphenol A interacts with the estrogen receptor $\alpha$ in a distinct manner from estradiol. Mol Cell Endocrinol 1998; 142(1-2): 203-14. [http://dx.doi.org/10.1016/S0303-7207(98)00084-7] [PMID: 9783916]

[201] Howdeshell KL, Hotchkiss AK, Thayer KA, Vandenbergh JG, vom Saal FS. Exposure to bisphenol A advances puberty. Nature 1999; 401(6755): 763-4. [http://dx.doi.org/10.1038/44517] [PMID: 10548101]

[202] Honma S, Suzuki A, Buchanan DL, Katsu Y, Watanabe H, Iguchi T. Low dose effect of in utero exposure to bisphenol A and diethylstilbestrol on female mouse reproduction. Reprod Toxicol 2002; 16(2): 117-22. [http://dx.doi.org/10.1016/S0890-6238(02)00006-0] [PMID: 11955942]

[203] Markey CM, Wadia PR, Rubin BS, Sonnenschein C, Soto AM. Long-term effects of fetal exposure to low doses of the xenoestrogen bisphenol-A in the female mouse genital tract. Biol Reprod 2005; 72(6): 1344-51. [http://dx.doi.org/10.1095/biolreprod.104.036301] [PMID: 15689538]

[204] Newbold RR, Jefferson WN, Padilla-Banks E. Long-term adverse effects of neonatal exposure to bisphenol A on the murine female reproductive tract. Reprod Toxicol 2007; 24(2): 253-8. [http://dx.doi.org/10.1016/j.reprotox.2007.07.006] [PMID: 17804194]

[205] Adewale HB, Jefferson WN, Newbold RR, Patisaul HB. Neonatal bisphenol-a exposure alters rat reproductive development and ovarian morphology without impairing activation of gonadotropin-releasing hormone neurons. Biol Reprod 2009; 81(4): 690-9. [http://dx.doi.org/10.1095/biolreprod.109.078261] [PMID: 19535786]

[206] Suzuki A, Sugihara A, Uchida K, et al. Developmental effects of perinatal exposure to bisphenol-A and diethylstilbestrol on reproductive organs in female mice. Reprod Toxicol 2002; 16(2): 107-16. [http://dx.doi.org/10.1016/S0890-6238(02)00005-9] [PMID: 11955941]

[207] Hunt PA, Koehler KE, Susiarjo M, et al. Bisphenol a exposure causes meiotic aneuploidy in the female mouse. Curr Biol 2003 ; $13(7)$ : 546-53. [http://dx.doi.org/10.1016/S0960-9822(03)00189-1] [PMID: 12676084]

[208] Susiarjo M, Hassold TJ, Freeman E, Hunt PA. Bisphenol A exposure in utero disrupts early oogenesis in the mouse. PLoS Genet 2007; 3(1): e5. [http://dx.doi.org/10.1371/journal.pgen.0030005] [PMID: 17222059]

[209] Toda K, Miyaura C, Okada T, Shizuta Y. Dietary bisphenol A prevents ovarian degeneration and bone loss in female mice lacking the aromatase gene (Cyp19). Eur J Biochem 2002; 269(8): 2214-22. [http://dx.doi.org/10.1046/j.1432-1033.2002.02879.x] [PMID: 11985600]

[210] Newbold RR, Jefferson WN, Padilla-Banks E. Prenatal exposure to bisphenol a at environmentally relevant doses adversely affects the murine female reproductive tract later in life. Environ Health Perspect 2009; 117(6): 879-85. [http://dx.doi.org/10.1289/ehp.0800045] [PMID: 19590677]

[211] Varayoud J, Ramos JG, Bosquiazzo VL, Muñoz-de-Toro M, Luque EH. Developmental exposure to Bisphenol a impairs the uterine response to ovarian steroids in the adult. Endocrinology 2008; 149(11): 5848-60. 
[http://dx.doi.org/10.1210/en.2008-0651] [PMID: 18653720]

[212] Bromer JG, Zhou Y, Taylor MB, Doherty L, Taylor HS. Bisphenol-A exposure in utero leads to epigenetic alterations in the developmental programming of uterine estrogen response. FASEB J 2010; 24(7): 2273-80. [http://dx.doi.org/10.1096/fj.09-140533] [PMID: 20181937]

[213] Shelby MD. NTP-CERHR monograph on the potential human reproductive and developmental effects of di (2-ethylhexyl) phthalate (DEHP). NTP CERHR MON 2006; 18(vii-7): II-iii-xiii.

[214] Jaakkola JJ, Knight TL. The role of exposure to phthalates from polyvinyl chloride products in the development of asthma and allergies: a systematic review and meta-analysis. Environ Health Perspect 2008; 116(7): 845-53. [http://dx.doi.org/10.1289/ehp.10846] [PMID: 18629304]

[215] Högberg J, Hanberg A, Berglund M, et al. Phthalate diesters and their metabolites in human breast milk, blood or serum, and urine as biomarkers of exposure in vulnerable populations. Environ Health Perspect 2008; 116(3): 334-9. [PMID: 18335100]

[216] Genuis SJ. Human elimination of phthalate compounds: blood, urine, and sweat (BUS) study. ScientificWorldJ $2012 ; 2012: 615068$.

[217] Völkel W, Kiranoglu M, Schuster R, Fromme H. Phthalate intake by infants calculated from biomonitoring data. Toxicol Lett 2014; 225(2): 222-9. [http://dx.doi.org/10.1016/j.toxlet.2013.12.012] [PMID: 24374175]

[218] Latini G, De Felice C, Presta G, et al. In utero exposure to di-(2-ethylhexyl)phthalate and duration of human pregnancy. Environ Health Perspect 2003; 111(14): 1783-5. [http://dx.doi.org/10.1289/ehp.6202] [PMID: 14594632]

[219] Swan SH, Main KM, Liu F, et al. Decrease in anogenital distance among male infants with prenatal phthalate exposure. Environ Health Perspect 2005; 113(8): 1056-61. [http://dx.doi.org/10.1289/ehp.8100] [PMID: 16079079]

[220] Suzuki Y, Yoshinaga J, Mizumoto Y, Serizawa S, Shiraishi H. Foetal exposure to phthalate esters and anogenital distance in male newborns. Int J Androl 2012; 35(3): 236-44.

[http://dx.doi.org/10.1111/j.1365-2605.2011.01190.x] [PMID: 21696396]

[221] Toft G, Jönsson BA, Lindh CH, et al. Association between pregnancy loss and urinary phthalate levels around the time of conception. Environ Health Perspect 2012; 120(3): 458-63. [http://dx.doi.org/10.1289/ehp.1103552] [PMID: 22113848]

[222] Frederiksen H, Sørensen K, Mouritsen A, et al. High urinary phthalate concentration associated with delayed pubarche in girls. Int J Androl 2012; 35(3): 216-26. [http://dx.doi.org/10.1111/j.1365-2605.2012.01260.x] [PMID: 22428786]

[223] Takai R, Hayashi S, Kiyokawa J, et al. Collaborative work on evaluation of ovarian toxicity. 10) Two- or four-week repeated dose studies and fertility study of di-(2-ethylhexyl) phthalate (DEHP) in female rats. J Toxicol Sci 2009; 34(Suppl. 1): SP111-9. [http://dx.doi.org/10.2131/jts.34.S111] [PMID: 19265277]

[224] Ma M, Kondo T, Ban S, et al. Exposure of prepubertal female rats to inhaled di(2-ethylhexyl)phthalate affects the onset of puberty and postpubertal reproductive functions. Toxicol Sci 2006; 93(1): 164-71. [http://dx.doi.org/10.1093/toxsci/kfl036] [PMID: 16763069]

[225] Svechnikova I, Svechnikov K, Söder O. The influence of di-(2-ethylhexyl) phthalate on steroidogenesis by the ovarian granulosa cells of immature female rats. J Endocrinol 2007; 194(3): 603-9. [http://dx.doi.org/10.1677/JOE-07-0238] [PMID: 17761899]

[226] Davis BJ, Maronpot RR, Heindel JJ. Di-(2-ethylhexyl) phthalate suppresses estradiol and ovulation in cycling rats. Toxicol Appl Pharmacol 1994; 128(2): 216-23. [http://dx.doi.org/10.1006/taap.1994.1200] [PMID: 7940536]

[227] Lovekamp-Swan T, Davis BJ. Mechanisms of phthalate ester toxicity in the female reproductive system. Environ Health Perspect 2003; 111(2): 139-45. [http://dx.doi.org/10.1289/ehp.5658] [PMID: 12573895]

[228] Pocar P, Fiandanese N, Secchi C, et al. Exposure to di(2-ethyl-hexyl) phthalate (DEHP) in utero and during lactation causes long-term pituitary-gonadal axis disruption in male and female mouse offspring. Endocrinology 2012; 153(2): 937-48. [http://dx.doi.org/10.1210/en.2011-1450] [PMID: 22147016]

[229] Zhang XF, Zhang LJ, Li L, et al. Diethylhexyl phthalate exposure impairs follicular development and affects oocyte maturation in the mouse. Environ Mol Mutagen 2013; 54(5): 354-61. [http://dx.doi.org/10.1002/em.21776] [PMID: 23625783]

[230] Wang W, Craig ZR, Basavarajappa MS, Gupta RK, Flaws JA. Di (2-ethylhexyl) phthalate inhibits growth of mouse ovarian antral follicles through an oxidative stress pathway. Toxicol Appl Pharmacol 2012; 258(2): 288-95. [http://dx.doi.org/10.1016/j.taap.2011.11.008] [PMID: 22155089]

[231] Tyl RW, Price CJ, Marr MC, Kimmel CA. Developmental toxicity evaluation of dietary di(2-ethylhexyl)phthalate in Fischer 344 rats and CD-1 mice. Fundam Appl Toxicol 1988; 10(3): 395-412. 
[http://dx.doi.org/10.1016/0272-0590(88)90286-2] [PMID: 3371580]

[232] Li R, Yu C, Gao R, et al. Effects of DEHP on endometrial receptivity and embryo implantation in pregnant mice. J Hazard Mater 2012; 241-242: $231-40$. [http://dx.doi.org/10.1016/j.jhazmat.2012.09.038] [PMID: 23046697]

[233] Grande SW, Andrade AJ, Talsness CE, et al. A dose-response study following in utero and lactational exposure to di-(2-ethylhexyl) phthalate (DEHP): reproductive effects on adult female offspring rats. Toxicology 2007; 229(1-2): 114-22. [http://dx.doi.org/10.1016/j.tox.2006.10.005] [PMID: 17098345]

[234] Hannon PR, Peretz J, Flaws JA. Daily exposure to Di(2-ethylhexyl) phthalate alters estrous cyclicity and accelerates primordial follicle recruitment potentially via dysregulation of the phosphatidylinositol 3-kinase signaling pathway in adult mice. Biol Reprod 2014; $90(6): 136$. [http://dx.doi.org/10.1095/biolreprod.114.119032] [PMID: 24804967]

Received: May 28, 2014 Revised: May 10, 2015 Accepted: June 5, 2015

(C) Zama et al.; Licensee Bentham Open

This is an open access article licensed under the terms of the Creative Commons Attribution-Non-Commercial 4.0 International Public License (CC BY-NC 4.0) (https://creativecommons.org/licenses/by-nc/4.0/legalcode), which permits unrestricted, non-commercial use, distribution and reproduction in any medium, provided the work is properly cited. 